\title{
Further species of Aphidoidea (Hom.) new to Finland
}

\author{
Osmo Heikinheimo
}

Heikinheimo, O. 1997: Further species of Aphidoidea (Hom.) new to Finland. — Entomol. Fennica 7: 159-185.

Forty aphid species with find records, diagnostic characters and some biometric data are represented as new to Finland. Six species are mentioned for the first time from the Nordic Countries. Nine species include descriptions of some morphs apparently for the first time. The record of Dysaphis aizenbergi Shaposhnikov from Finland (Heikinheimo 1990) was based on a misidentification. The species should be Brachycaudus linariae Stroyan. The status of Iziphya austriaca Börner, 1950 as a good species is discussed.

Osmo Heikinheimo, Department of Applied Zoology, P.O. Box 27, FIN00027, University of Helsinki, Helsinki, Finland

Received 14 March 1995, accepted 15 August 1995

\section{Introduction}

Since Huldén and Heikinheimo (1984) published the check-list of Finnish aphids, a large number of aphid samples, old and new, have been mounted and examined. Since then several further species new to Finland have been published (Huldén 1985, Heikinheimo 1990, 1991, 1992, Heie 1992, 1994, Albrecht 1992a-d, 1993a-g 1994a-d). Three of the species represented here have been mentioned earlier by Heie $(1992,1994)$ and Pintera (1987). The descriptions of apparently new morphs have been indicated with morph names written in italics. The species new to Nordic countries are marked with an asterisk. When not mentioned, the collector of the aphid samples is the author. Many aphid samples were captured with a wind net trap (wnt) in the 1960s (Heikinheimo 1984). The name of the locality Vantaa was at that time the Helsinki rural municipality, but it is labeled in this paper with its current name. The symbols of biological provinces are the same as in the series Fauna Entomologica Scandinavica. The $10 \times 10-\mathrm{km}$ square grid references are represented according to the system of Grid $27^{\circ} \mathrm{E}$ (Heikinheimo \& Raatikainen 1981).
Abbreviations and symbols:

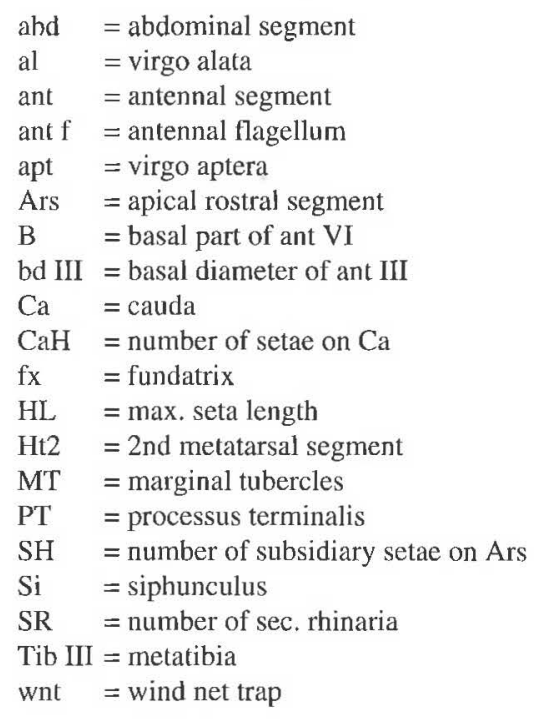

Species included in this paper:

1. Glyphina pseudoschrankiana Blackman, 1989

2. Pachypappa vesicalis Koch, 1856

3. Prociphilus bumeliae (Schrank, 1801)

4. Pemphigus spyrothecae Passerini, 1856 
5. Callipterinella minutissima (Stroyan, 1953)

6. Calaphis arctica Hille Ris Lambers, 1952

7. Tuberculatus (T.) querceus (Kaltenbach, 1843)

8. Therioaphis tenera (Aizenberg, 1956)

9. Thripsaphis (T.) caespitosae Ossiannilsson, 1954

10. Thripsaphis (Larvaphis) brevicornis Ossiannilsson, 1953

11. Iziphya bufo (Walker, 1848)

12. Chaitophorus furcatus Pintera, 1987

13. Chaitophorus ramicola (Bömer, 1949)

14. Rhopalosiphum rufiabdominale (Sasaki, 1899)

15. Melanaphis elisabethae (Ossiannilsson, 1967)

16. Schizaphis agrostis Hille Ris Lambers, 1947

17. Schizaphis dubia Huculak, 1968

18. Schizaphis jaroslavi (Mordvilko, 1921)

19. Schizaphis nigerrima (Hille Ris Lambers, 1931)

20. Schizaphis (Paraschizaphis) caricis (Schouteden, 1906)

21. Aphis avicularis (Linné, 1761)

22. Aphis fabae mordvilkoi Börner \& Janisch, 1922

23. Aphis genistae Scopoli, 1763

24. Aphis longirostrata Hille Ris Lambers, 1966

25. Aphis podagrariae Schrank, 1801

26. Aphis umbrella (Börner, 1950)

27. Brachycaudus (Acaudus) aconiti (Mordvilko, 1928)

28. Brachycaudus (Acaudus) linariae Stroyan, 1957

29. Semiaphis anthrisci (Kaltenbach, 1843)

30. Coloradoa inodorella Ossiannilsson, 1959

31. Ossiannilssonia oelandica Hille Ris Lambers, 1952

32. Myzus (Nectarosiphon) certus (Walker, 1849)

33. Submegoura heikinheimoi (Börner, 1952)

34. Sitobium paludum F, P. Müller, 1982

35. Delphiniobium junackianum (Karsch, 1887)

36. Macrosiphoniella dimidiata Börner, 1942

37. Uroleucon (U.) jaceicola Hille Ris Lambers, 1939

38. Megourella purpurea Hille Ris Lambers, 1949

39. Galiaphis annae Ossiannilsson, 1954

40. Eulachnus brevipilosus (Börner, 1940)

\section{Thelaxidae}

\section{*1. Glyphina pseudoschrankiana}

According to Blackman (1989), the species Glyphina scrankiana sensu Szelegiewicz (1982) includes two different species, viz. G. schrankiana $(2 \mathrm{n}=10)$ living on Alnus and a new species G. pseudoschrankiana $(2 \mathrm{n}=28$ or 56$)$, living on Betula. All Glyphina populations found on Alnus in Finland belong to G. schrankiana sensu Blackman, and the others, the old "G. schrankiana" found on Betula, belong to G. pseudoschrankiana. All three Glyphina species seem to be about equally common in Finland, more common in southeastern parts than elsewhere in the country.

Material: $A b$ : Turku 671:24 apt and al on Betula; Tenhola 665:29 Betula pendula 14.VI.1992, Kiikala 670:31
B. pubescens 22.VI.1993 (A. Albrecht leg.); $N$ : Espoo 667:37 fx on B. pendula 21.V.1983; Hanko 664:27 apt on Cirsium and Tripleurospermum 26.VII.1962 (Jussi Nuorteva leg.); Hanko, Tvärminne 664:28 apt. on Betula alba 13.VI.1945; Vantaa 668:39 al from wnt 17.VII.1963; on $B$. pendula, B. pubescens 8.VII.1992 (A. Albrecht leg.); Vantaa 668:39 al from suction trap 27.VI.1982; Sipoo 668:41 B. pubescens 26.VI.1993, 669:40 B. pendula 7.VII.1992, Askola 671:41 B. pendula 9.VII.1992, Hyvinkää 671:37 B. pendula, B. pubescens 26.VI.1992, Ka: Miehikkälä 633:53 apt, al B. pubescens 10.VI.1992 (A Albrecht leg.); Sa: Mikkeli 684:51 al from wnt 7-11.VI.1963, 21.VI.18.VII.1966, 2-23.VI.1967; Mikkeli, Otava 683:50 apt on Betula sp. 15.VI.1937 (Veikko Kanervo leg.); Kl: Parikkala 682:63 apt and al on Betula alba and pubescens 27.VI.1990; $K b$ : Liperi 695:62 apt and al on Betula pubescens; Om: Kokkola 708:31 B. pubescens 5.VIII.1992 (A. Albrecht leg.); Revonlahti 717:40 al from wnt 6-7.VII.1962; Ob: Oulunsalo 721:41 Betula pubescens 4.VIII.1992 (A. Albrecht leg.).

Diagnostic characters: In G. pseudoschrankia$n a$ the length of ant $\mathrm{B}(0.135-0.160 \mathrm{~mm})$ is greater than in G. schrankiana $(0.103-0.134 \mathrm{~mm})$, and the lengths of setae on the abdomen are more than $50 \mu \mathrm{m}$ in G. pseudoschrankiana but less than $50 \mu \mathrm{m}$ in G. schrankiana.

\section{Pemphigidae}

\section{Pachypappa vesicalis (Fig. 1)}

Material: Al: Jomala, Jomalaby 669:11 sexupara alata from wnt 24.VII.1962.

Diagnostic characters: Heikinheimo (1992) reported Pachypappella lactea (Tullgren), Pachypappa tremulae (L.) and P. populi (L.) from Åland. These materials include mostly sexuparae whose diagnostic characters were very poorly known. During my studies made in 1989-1990 on trapped sexuparae, morphological differences were found between those three species mentioned above (Table 1). However, in evaluating the right names of the three species, which names of the species were in question in each case, two species erroneously changed names with each other. Simultaneously, Carter and Danielsson (1991) reared the Pachypappa and Pachypappella species and clarified their biology and some morphological differences between the sexuparae. Therefore, the following corrections in the contribution of Heikinheimo (1992: 59) are needed: Write Pachypappella lactea (Tullgren) instead of Pachypappa po- 


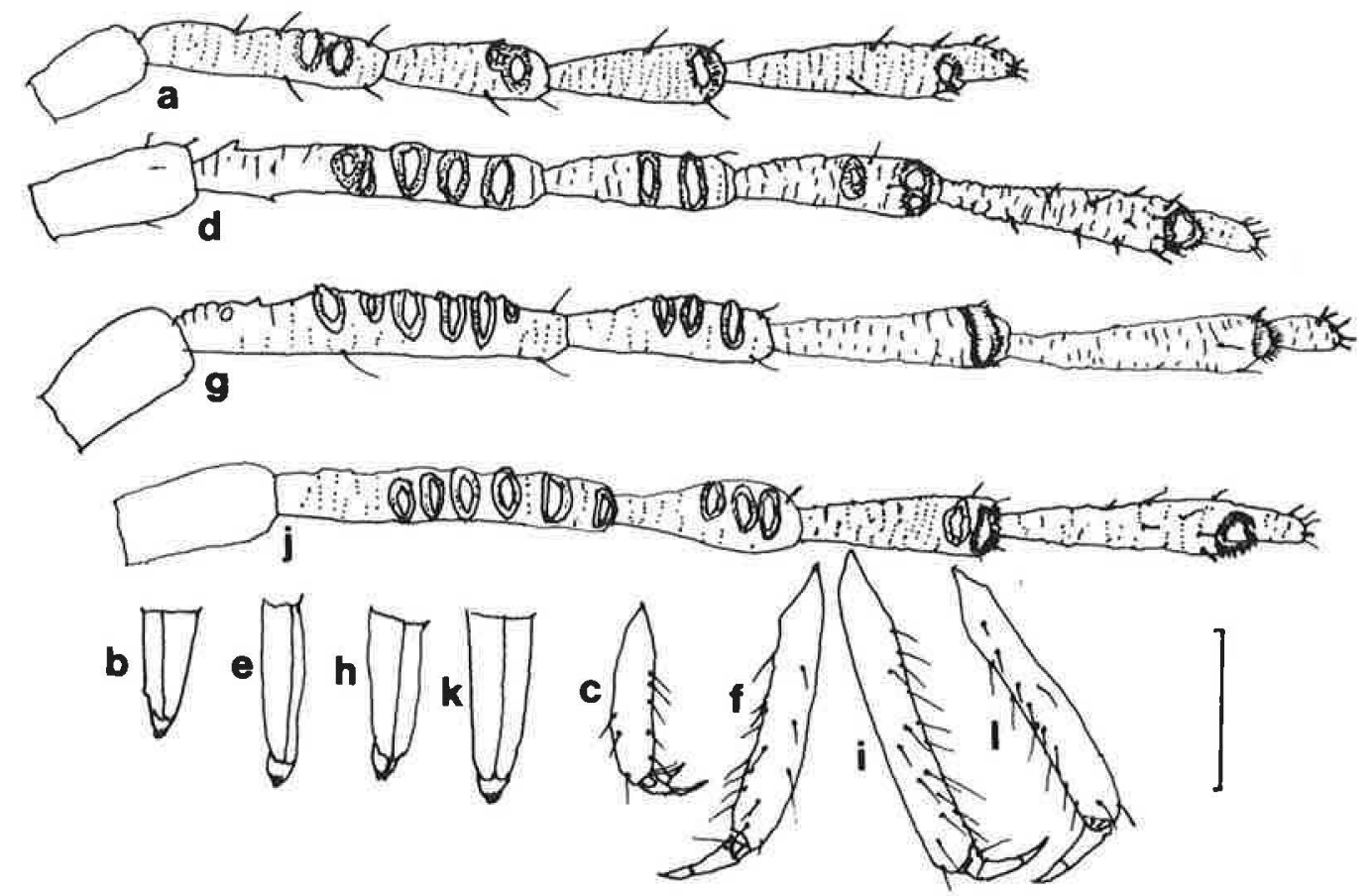

Fig. 1. Sexuparae alatae of Pachypappella lactea (Tullgren) (a-c), Pachypappa tremulae (Linnaeus) (d-f), $P$. populi (Linnaeus) ( $\mathrm{g}-\mathrm{i})$ and $P$. vesicalis Koch (j-l). Antennal segments II-VI (a, d, g, j); apical rostral segment $(b, e, h, k)$; second metatarsal segment with claws (c, f, i, l). Scale $0.1 \mathrm{~mm}$.

Table 1. Morphological characters measured from sexuparae of different Pachypappella and Pachypappa species collected in Finland.

\begin{tabular}{|c|c|c|c|c|}
\hline Measurements & $\begin{array}{l}\text { lactea } \\
\mathrm{n}=31\end{array}$ & $\begin{array}{c}\text { tremulae } \\
\mathrm{n}=21\end{array}$ & $\begin{array}{c}\text { populi } \\
\mathrm{n}=6\end{array}$ & $\begin{array}{c}\text { vesicalis } \\
\mathrm{n}=1\end{array}$ \\
\hline Body, mm & $0.87-2.00$ & $1.54-2.80$ & $1.65-2.70$ & 2.03 \\
\hline Ant segm. III, $\mu \mathrm{m}$ & $102-167$ & $163-272$ & $196-255$ & 226 \\
\hline Ant segm. IV, $\mu \mathrm{m}$ & $65-112$ & $92-160$ & $81-150$ & 120 \\
\hline Ant segm. $V, \mu \mathrm{m}$ & $78-120$ & $105-180$ & $110-155$ & 130 \\
\hline Ant segm. $B+P T, \mu m$ & $146-188$ & $180-256$ & $165-180$ & 161 \\
\hline Ars, $\mu \mathrm{m}$ & $55-102$ & $105-130$ & $102-112$ & 31 \\
\hline Ars mean, $\mu \mathrm{m}$ & 83 & 105 & & \\
\hline $\mathrm{Ht} 2, \mu \mathrm{m}$ & $110-158$ & $185-250$ & $180-242$ & 195 \\
\hline $\mathrm{H}+2$ mean, $\mu \mathrm{m}$ & 136 & 205 & & \\
\hline \multicolumn{5}{|l|}{ Length ratios: } \\
\hline Body/Ars & $11.6-25.0$ & $12.6-21.9$ & $15.0-21.4$ & 16.9 \\
\hline Body/Ars mean & 17.35 & 16.74 & & \\
\hline $\mathrm{Body} / \mathrm{Ht} 2$ & $6.84-12.67$ & $7.91-12.1$ & & \\
\hline Body/Ht2 mean & 10.47 & 9.43 & & \\
\hline Ars $/ \mathrm{Ht} 2$ & & $0.50-0.54$ & 0.62 & 0.67 \\
\hline Ant PT/B & & & $0.25-0.31$ & 0.20 \\
\hline \multicolumn{5}{|l|}{ Number of: } \\
\hline SR on III & $2-3$ & $2-6$ & $5-8$ & $5-6$ \\
\hline SR on IV & $1-2$ & $1-3$ & $2-3$ & $2-3$ \\
\hline SR on $\mathrm{V}$ & 0 & 0 & $O(1)$ & 0 \\
\hline Setae on ant B & & $5-20$ & $1-3$ & $4-7$ \\
\hline Dotting on sec rhin & \multicolumn{2}{|c|}{ Distinct and complete } & \multicolumn{2}{|c|}{ Indistinct and incomplete } \\
\hline
\end{tabular}




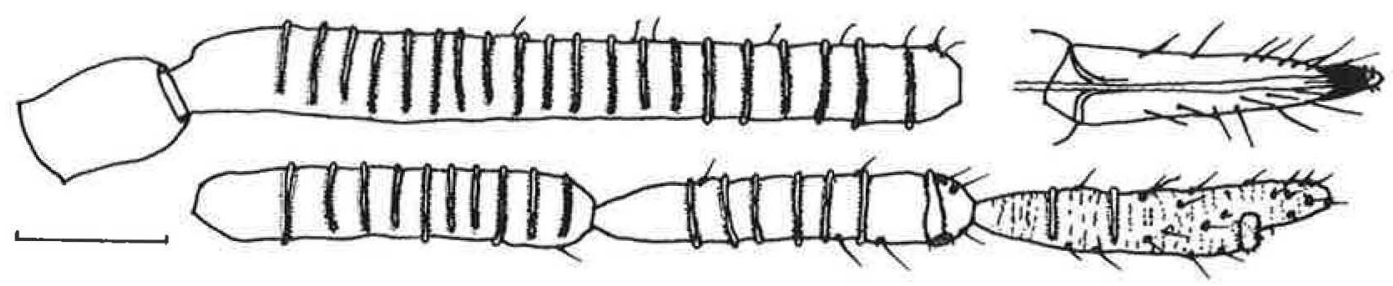

Fig. 2. Antenna and apical rostral segment of sexupara alata of Prociphilus bumeliae (Schrank) (Ant. segment ( omitted). Scale $0.1 \mathrm{~mm}$.

puli (Linnaeus), and Pachypappa populi (Linnaeus) instead of Pachypappella lactea (Tullgren). According to the diagnostic characters represented by Carter and Danielsson (1991), one of the $\mathrm{Pa}$ chypappa populi sexuparae from Åland proved to be Pachypappa vesicalis Koch.

The most striking diagnostic characters of Pachypappella lactea are the short apical rostral segment and short metatarsus, and the small number of secondary rhinaria. In Pachypappa tremulae the number of setae on ant $B$ is the highest, and the dotting of sec. rhinaria on ant III is distinct. In $P$. populi the number of setae on ant B is small, and the dotting of sec rhinaria indistinct and incomplete. P. vesicalis differs from $P$. populi sexuparae in the different length ratio $\mathrm{PT} / \mathrm{B}$, in the longer Ars in P. vesicalis, and in the higher number of setae on ant $\mathrm{B}$.

\section{Prociphilus bumeliae (Fig. 2)}

Material: $U$ : Vantaa 668:39 alate sexuparae from suction trap 8-11.X.1981, 27.IX.1982 and 4.X.1982; Sa: Mikkeli 684:51 alate sexupara from wnt 3.X.1967.

Diagnostic characters: Besides the characters mentioned by Heie (1980), P. bumeliae differs distinctly from $P$. (Stagona) xylostei (De Geer, 1773) and $P$. (Stagona) pini (Burmeister, 1835) in having long $(0.23 \mathrm{~mm})$ Ars with more than 10 prominent SH (in P. xylostei and P. pini $0.09-0.13 \mathrm{~mm}$ and with some minute SH). Sexuparae of $P$. bumeliae have SR also on ant VI. The aphids are remarkably larger (about $3 \mathrm{~mm}$ ) than the sexuparae of the other species (1.0-1.7 mm) mentioned above.

\section{Pemphigus spyrothecae}

Material: $N$ : Helsinki 667:38 galls with numerous apterous and alate aphids on Populus nigra 14.IX.1986 (Sirkka-Liisa \& Pekka Nuorteva leg.).

The twisted galled leaf petioles and the permanently living of the species in these are typical characters of this species. Other characters in Heie (1980).

\section{Drepanosiphidae}

\section{Callipterinella minutissima (Fig. 3)}

Material: $N$ : Vantaa 668:39 al from wnt 1.VI.1962; male al from suction trap 28.IX.1982; Sa: Mikkeli 684:51 al from wnt 11.VI.1963 and 12.VI.1966; ObN: Rovaniemi rural mun. 738:45 al and male al from wnt 6-7.VII.1962 and 24.VIII. 1967.

Diagnostic characters: The alate viviparous females and males found in Finland fit well with the descriptions of Stroyan (1953), except for the alate females, in which the ratio PT/B is 1.89 and 2.04. These lack pigmentation on the body as a whole. The number of secondary rhinaria varies from 4-7 in all specimens.

\section{*6. Calaphis arctica (Fig. 4)}

Material: Ab \& St: Nousiainen \& Yläne, Kuhankuono 674:25 apt 23.VII.1994 (O. Heikinheimo \& A. Albrecht leg); Ta: Janakkala 674:37 apt, al, ovip 11.VII.-30.VIII.1985, 676:38 apt 28.VII.1994; Sa: Leivonmäki 686:44 fundatrix 13.VI.1987; Tb: Laukaa 700:35 al 4.VII.1985; Sb: Varpaisjärvi 702:54 apt 16.VI.1988; Om: Vimpeli 700:35 apt, al, ovip. 10.VII.28.VIII. 1985; Alajärvi 699:33 apt 6.-7.VII.1985; Kn: Paltamo 714:55 apt 2.VII.1991. All finds on Betula nana.

Diagnostic characters: The species in closest to C. betulicola in having its SR near the middle in ant III, and siphunculi with dark to black apices, not wholly pale as mentioned in the original description of Hille Ris Lambers (1952a). It has slightly 


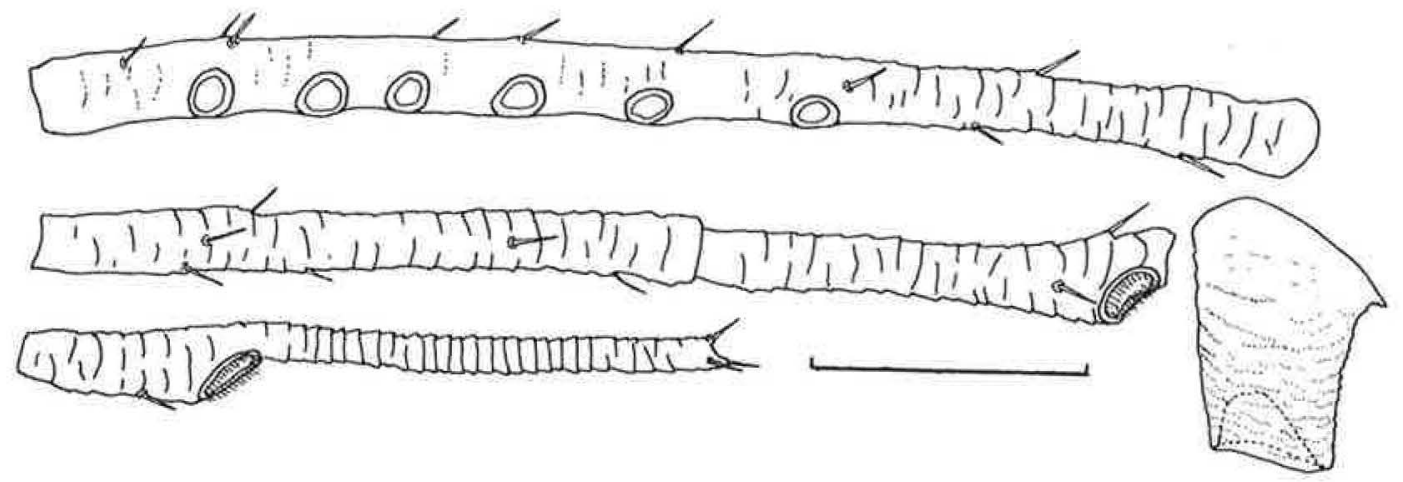

Fig. 3. Callipterinella minutissima (Stroyan). Antennal segments III-VI and siphunculus. Scale $0.1 \mathrm{~mm}$.

shorter legs than C. flava and C. betulicola, and the body is more broadly oval. Another deviation from the original description is that the prominent dor- sal setae and their conical bases are dusky or dark, unlike in C. betulicola and C. flava. The characters of the specimens of different morphs from

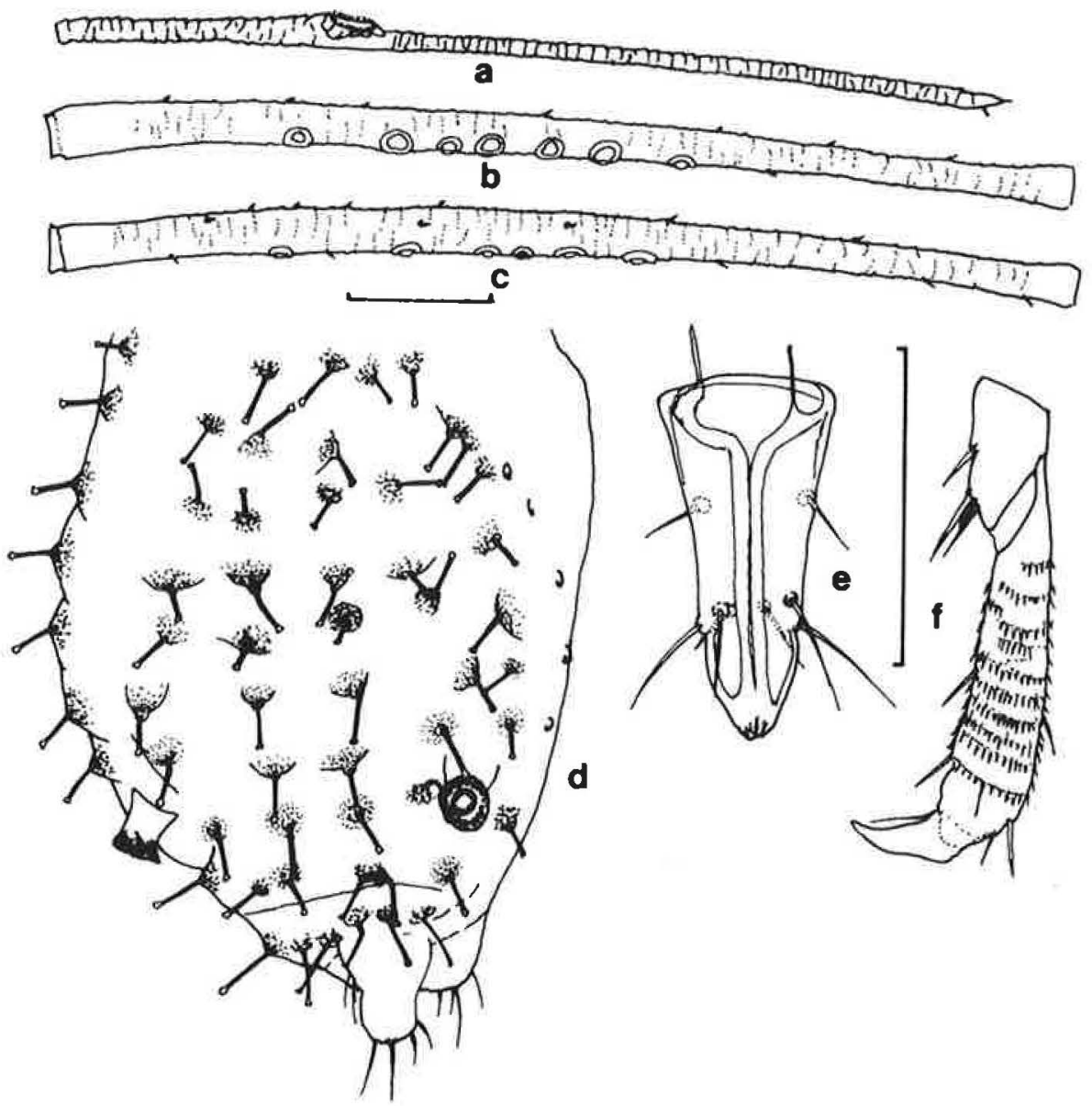

Fig. 4. Calaphis arctica Hille Ris Lambers. Virgo alata (a, b) and aptera (c-f). a: antennal segment VI; b, c: antennal segment III; dorsal setae and siphunculi on abdomen; e: apical segment of rostrum; f: metatarsus. Scales $0.1 \mathrm{~mm}$. 

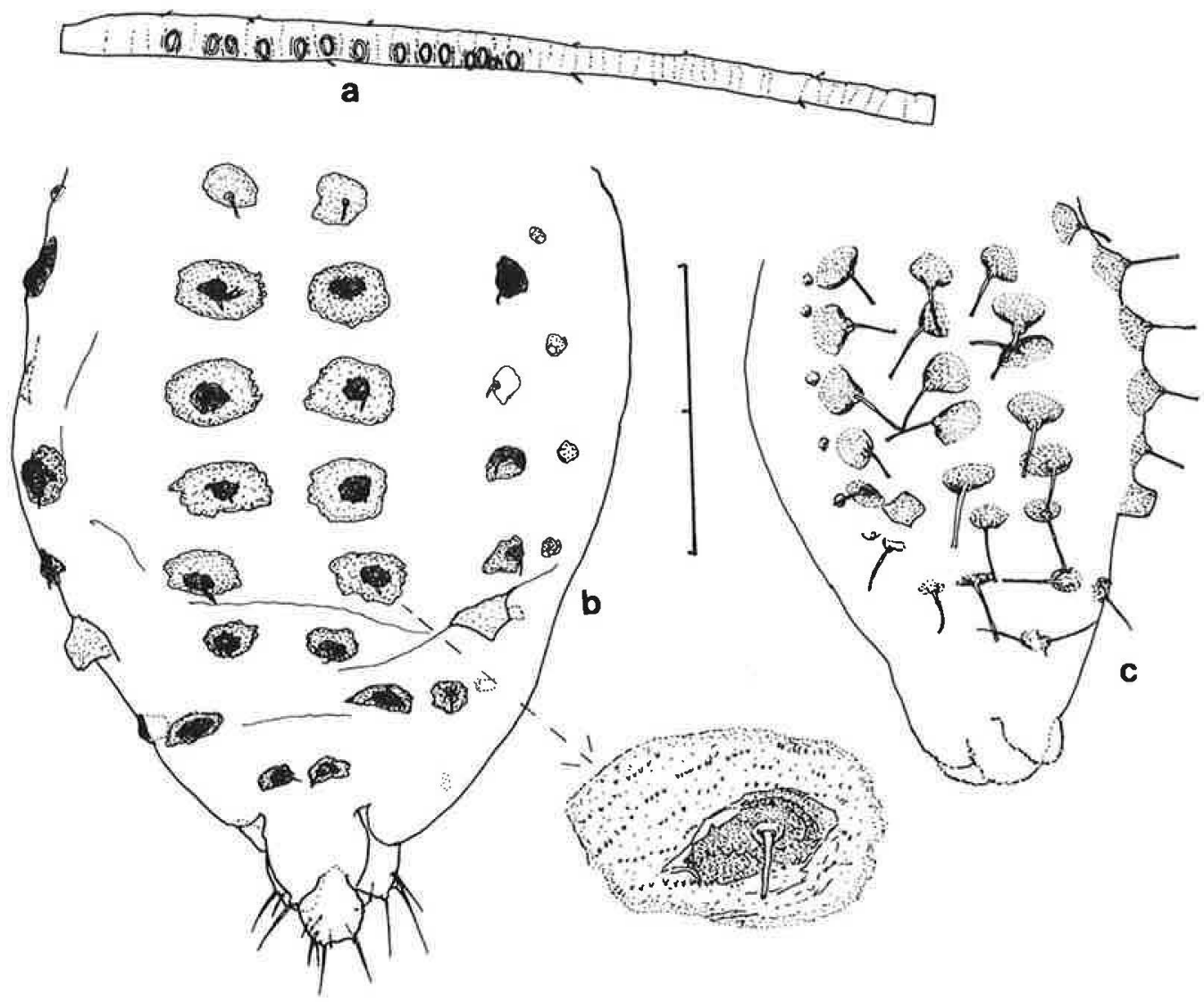

Fig. 5. Therioaphis tenera (Aizenberg). Virgo alata (a, b) and ovipara (c). a: antennal segment III; b, c: sclerotic patterns on abdomen. Scale $0.2 \mathrm{~mm}$.

Finland are more like those described later from Europe (Stroyan 1953, Hille Ris Lambers 1959).

\section{Tuberculatus querceus}

Material: $N$ : Vantaa 668:39 al from wnt 20.VII.1966.

Diagnostic characters: This rare species differs in life from Tuberculoides spp. in being covered with a white waxy powder. The peculiar glovelike spinal tubercle with two finger-like apices on abd III is rather low in the specimen from Finland, but it distinctly has a common basal part.

\section{*8. Therioaphis tenera (Fig. 5)}

Material: $A b$ : Turku 671:62 al 2.VII. and 28.VII.1994; $N$ : Helsinki 667:38 al 31.VII.1985; Vantaa 668:39 al 26.VI.1985;
Sipoo, Nickby 669:40 28.V.1993 (A. Albrecht leg.); St: Yläne 675:25 al 28.VII.1994; Ta: Jokioinen 674:30 ovip 27.VIII.1985; Janakkala 675:36 al 24.VII.1985; Hämeenlinna 676:36 al 19.VII.1985, 2.VIII.1994; Pälkäne 680:35 fx, al, ovip 30.VI.-3.IX.1985; Hartola 682:44 fx 13.VI.1988; Sb: Nilsiä 701:55 LL 17.VI.1988; Kuopio 697:53 LL. All records from Caragana arborescens; $N$ : Vantaa 668:39 al 19.VII.-2.VIII.1982 from suction trap.

Diagnostic characters: Shaposhnikov (1964) described the species in his key. The species most resembles T. riehmi (Börner, 1949). Both have dorsal tubercles in four rows, the pleural rows absent. The sclerites around the spinal tubercles vary in size; their diameter is usually about as wide as the space between them. In $T$. riehmi the sclerites and the tubercles in their middle are dark, clearly visible even in living specimens. In $T$. tenera the sclerites are pale, hardly visible in living specimens. The tubercles in their middle are slightly dark. The siphunculi of T. riehmi are dark, of 
T. tenera pale. The length of setae on the spinal tubercles on abd III-VI are short, 10-14 $\mu \mathrm{m}$ in T. riehmi, longer $(35-60 \mu \mathrm{m})$ in T. tenera.

The dorsal pattern of alate male of $T$. tenera is similar to that of the female; the spots are smoky, the siphunculi pale. Secondary rhinaria on ant III 18-19, IV 4-7, V 0-4.

Oviparae are apterous, with pale dorsal spinal sclerites and long setae $(70-80 \mu \mathrm{m})$ in their middle. Metatibiae are swollen in their $2 / 3$ part, with about 30-50 scent plaques. Ant III with 10-15 sec. rhinaria in their basal $1 / 2-3 / 5$ parts.

Biology: The aphids live dispersed beneath leaflets, mostly in lower branches.

\section{Thripsaphis (T.) caespitosae (Fig. 6)}

Material: LkE: Sodankylä 758:51 LL on Carex sp. 6.VII.1989.

Diagnostic characters: Ossiannilsson (1954) described all morphs thoroughly. The larvae (fourth. nymphal stage, two exx.) fit the typical descriptions of Thripsaphis s.str., viz. six-segmented antennae, spatulate empodial hairs and pointed dorsal hairs. A conspicuous character, also appearing in the nymphal stage, is the numerous spine-like pointed setae, $15-20 \mu \mathrm{m}$ long, all over the dorsum, about 40-50 per segment. The species has been regarded as a subspecies of Thripsaphis (T.) balli (Gillette, 1908) (Ossiannilsson 1954, Heie 1982).

\section{Thripsaphis (Larvaphis) brevicornis (Fig. 7)}

Material: Ta: Janakkala 676:38 apt and ovip on Carex lasiocarpa 8.IX.1991 (Veli Vikberg leg.).

Diagnostic characters: In having very short fivesegmented antennae, the species differs distinctly from all other Saltusaphidine species. It is distinctly related to Thripsaphis s.str. in having numerous very short $(12-15 \mu \mathrm{m})$ spines on the abdominal segments, about 70-80 in number on each, situated on small isolated scleroites (Ossiannilsson 1953).

\section{Iziphya bufo}

Material: N: Hanko, Tvärminne: 664:28 apt, al, ovip 4.VII,21.IX.1986, apt 24.VIII.1993 (A. Albrecht leg.). Both on Carex arenaria.
Diagnostic characters: According to Szelegiewicz (1976), Heie (1982), and Quednau (in litt.), I. bufo and I. austriaca cannot be separated on the basis of morphological characters. I have tried to find any differences in the morphology of these two species and found only weak signs of such differences:

- I. bufo: The dusky area along the costal vein of the hindwing extends to the very tip of the wing, and curves further backwards to some extent along the border of the tip of the wing (Fig. 8).

- I. austriaca: The dusky area along the costal vein of the hindwing vanishes before reaching the very tip of the border of the wing.

The dusky areas along the wing veins seem broader and slightly darker in I. bufo than in I. austriaca, but this character varies so much in both species that the difference is too obscure. In the oviparous females the metatibiae are thicker and darker in I. bufo than in I. austriaca. The ratio length/ maximal diameter of metatibia is: 4.62(5.68)6.55 in I. bufo, 6.00(6.97)7.46 in I. austriaca. Between apterous viviparous females I could find no discriminant characters of diagnostic value.

It is remarkable that $I$. bufo could be reared with success on C. canescens. In both species the first generations seem to be bigger and their dark pigment areas on the dorsum more restricted than in the generations later in summer.

Conclusions: According to my findings, Iziphya bufo and I. austriaca cannot be good taxons on the species level, but they may present two different biological races or subspecies of a common species. This question is still open until further studies, e.g. cross-breeding experiments, have been made.

\section{*12. Chaitophorus furcatus}

Material: $T b$ : Rautalampi 694:49 apt 19. and 30.VII.1983, apt ovip and males 17.VII.-21.VII., 18.VIII,-3.X.1985.

Diagnostic characters: Pintera (1987) described thoroughly the different morphs of this species and mentioned also the records of this species from Finland. Alive, the apterae are dull pale yellow, pearly-like but slightly flattened in shape. 


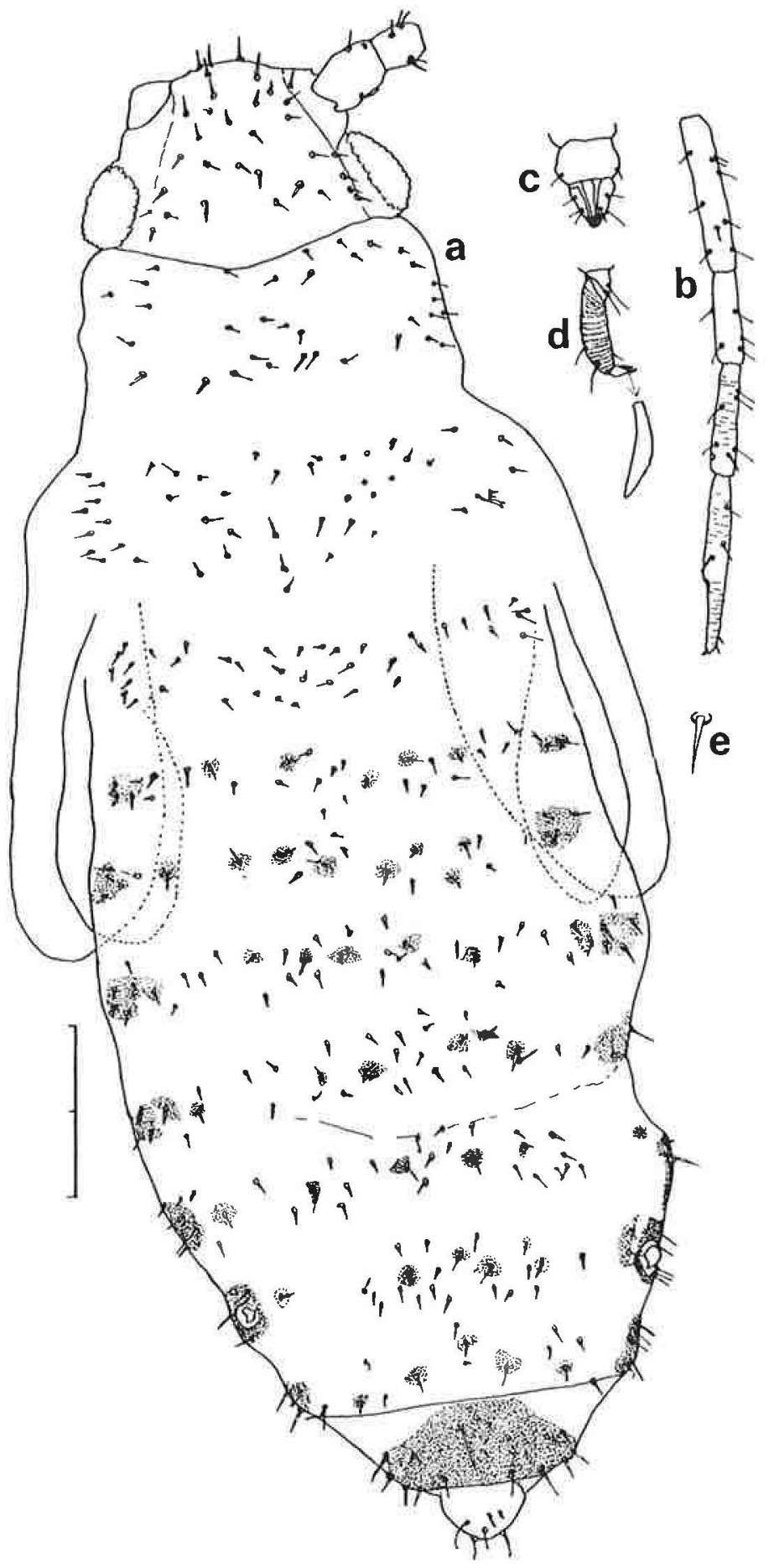

Fig. 6. Thripsaphis (T.) caespitosae Ossiannilsson. Nymph. a, e: dorsal setae; b: antennal segments III-VI; c: apical segments of rostrum; d: metatarsus. Scale $0.2 \mathrm{~mm}$.
Biology: A special feature of this species is that it has been found in all cases only on the same single Salix caprea, accompanied by Chaitophorus salicti (Schrank, 1801) and Lasius niger. In other Salix caprea nearby, only $C$. salicti could be found. From mid-July onwards, no alatae have been found. Perhaps they occur rarely only in the second generation. 
Fig. 7. Thripsaphis (Larvaphis) brevicornis Ossiannilsson. Virgo aptera $(a-d, f, g)$ and ovipara (e). a: antennal segments II-VI; b: apical rostral segment; c: metatarsus; d: anterior part of the head; e: metatibia of ovipara; $f:$ abdominal segment Vl; g: abdominal segment VIII and cauda. Scale $0.2 \mathrm{~mm}$.
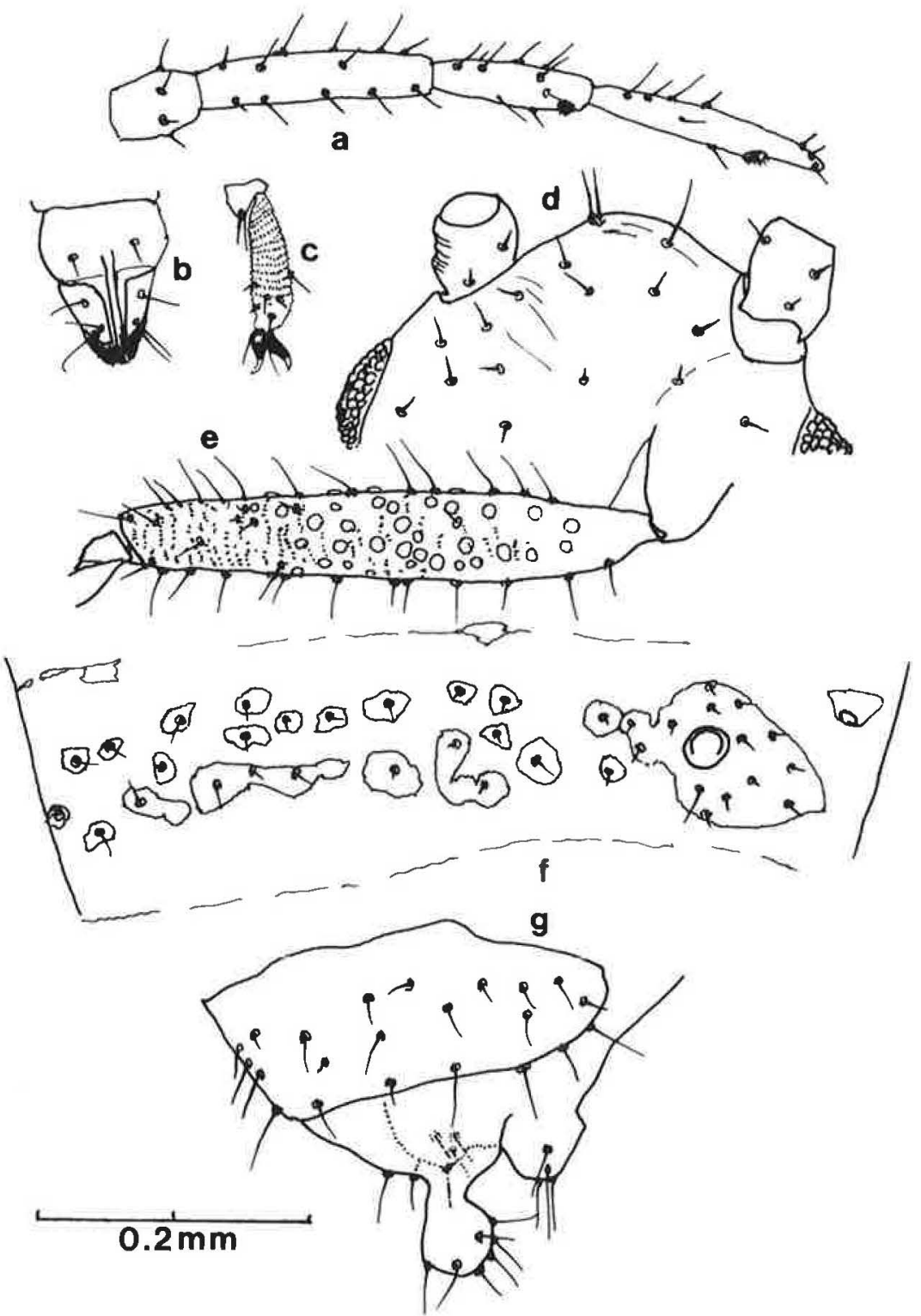

\section{Chaitophorus ramicola}

Material: $A b$ : Turku: 671:24 apt on Salix sp. 26.VII.1994 (A. Albrecht, Ole Heie \& O. Heikinheimo leg.); Vihti, Ojakkala 669:35 24.VII.1994 a colony on Salix caprea (A. Albrecht, O. Heie \& O. Heikinheimo leg.); $N$ : Helsinki 668:37 and Vantaa 668:39 apt, ovip and males 9.IX. and 23.IX.1945 on Salix caprea; Porvoo rural mun., Sondby 668:43 colonies on Salix caprea (A. Albrecht leg.); Sipoo, Nevas 668:41 16.VII.1991 a colony, 12.X.1991 ovip., both on Salix caprea, 3.IX.1994 a colony on Salix aurita (A. Albrecht leg.); Kirkkonummi, Lillkanskog 665:35 23.VIII.1991, a colony on Salix caprea (A. Albrecht leg.); Tuusula, Ristikivenmäki 670:38 18.VII.1992 a colony on Salix caprea (A. Albrecht leg.); Ta: Heinola rural mun. 679:44 apt 28.VII.1994 on Salix phylicifolia (A. Albrecht, Ole Heie and $\mathrm{O}$. Heikinheimo leg.).

Diagnostic characters: On Salix caprea two species of Chaitophorus have apterous males, viz: C. ramicola and C. furcatus. They look quite different: the former are dark brown and live on twigs, the latter are pale dull yellow and live on leaves. 


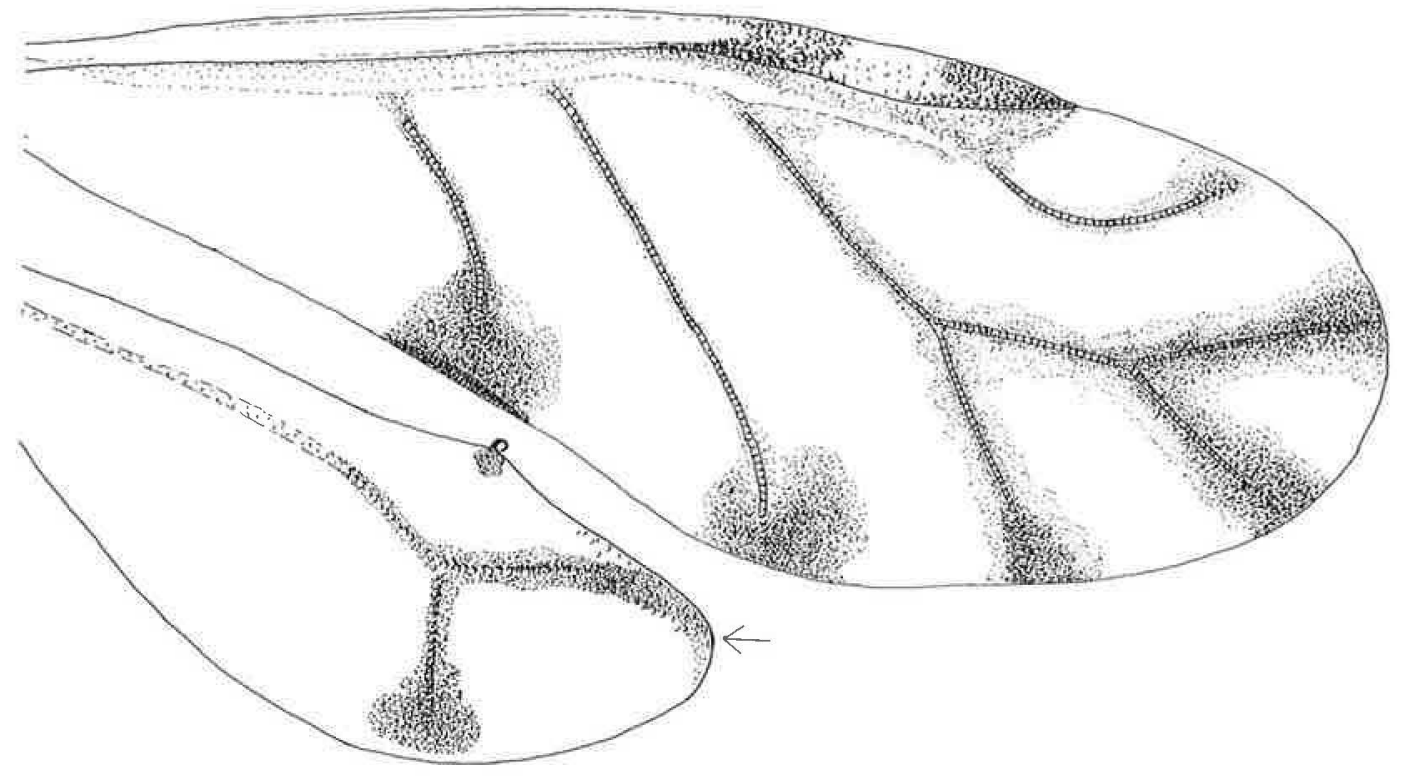

Fig. 8. Right wings of Iziphya bufo (Walker). Sexupara.

\section{Aphididae}

\section{Rhopalosiphum rufiabdominale}

Material: Noormarkku St: 684:22 apt and al on Dieffenbachia sp. in a greenhouse (imported) 26.VII.1984.

Diagnostic characters: The most conspicuous character is the length of the setae, on ant III of apt about $4 \times$ bd III.

\section{Melanaphis elisabethae (Fig. 9)}

Material: $N$ : Helsinki rural mun. 668:39 al 1-12.VII.1966; Sa: Mikkeli 684:51 al 1-21.VII.1963, 7-12.VII.1968. All from wnt.

Diagnostic characters: Ossiannilsson (1967) originally described the apterous viviparous females. The alate females captured in Finland deviate in some respects from the descriptions of Heie (1986): The ratio PT/B is 1.7-2.1 (in Heie: 2.6), ant f/body $0.55-0.67$, Si/body $0.6-0.8, \mathrm{Si} /$ $\mathrm{Ca} 0.56-0.76$, Ars/Ht2 0.6-0.7. Secondary rhinaria on each ant are: III 6-10, IV 0-2, V 0-3. Cauda with $7-11$ hairs. The short slightly vasiform to almost cylindrical siphunculi and the very short apical rostral segment are remarkable characters of this species. In general appearance they much resemble Hyalopterus but are smaller, and the black siphunculi with a flange are more conspicuous.

\section{Schizaphis agrostis}

Material: Sa: Mikkeli 684:51 al from wnt 28. and 30.VII.1967; Oa: Koivulahti 702:23 in flying VI.1956; Laihia 699:24 fx and apt on Carex-Agrostis meadow 7.VI.1957; Om: Revonlahti 717:40 al from wnt 10.25.VII.1962; Kn: Kuhmo 714:60 fx on Melica nutans 29.VI.1965; $O b N$ : Rovaniemi rural mun. al from wnt 26. and 30.VII. 1963.

Diagnostic characters: As a member of the Schizaphis graminum (Rondani, 1852) complex (Pettersson 1971a) the aphids have a pale green body, pale Si and Ca and short Ars. Small MT are on abd segments I, II and VII. On apterous and alate specimens collected in Finland the ratio PT/ $\mathrm{B}$ is 2.61(3.67)4.30 and $\mathrm{Si} / \mathrm{Ca} 1.23(1.30) 1.41$. In the closely related $S$. borealis (Tambs-Lyche 1959) the ratio $\mathrm{Pt} / \mathrm{B}$ is similar to that in S. agrostis, but $\mathrm{Si} / \mathrm{Ca}$ is less than 1.2, mostly 1.0-1.1.

Biology: S. agrostis lives on Agrostis, and on $\mathrm{Poa}$ and on some other small grains. The male is alate. 


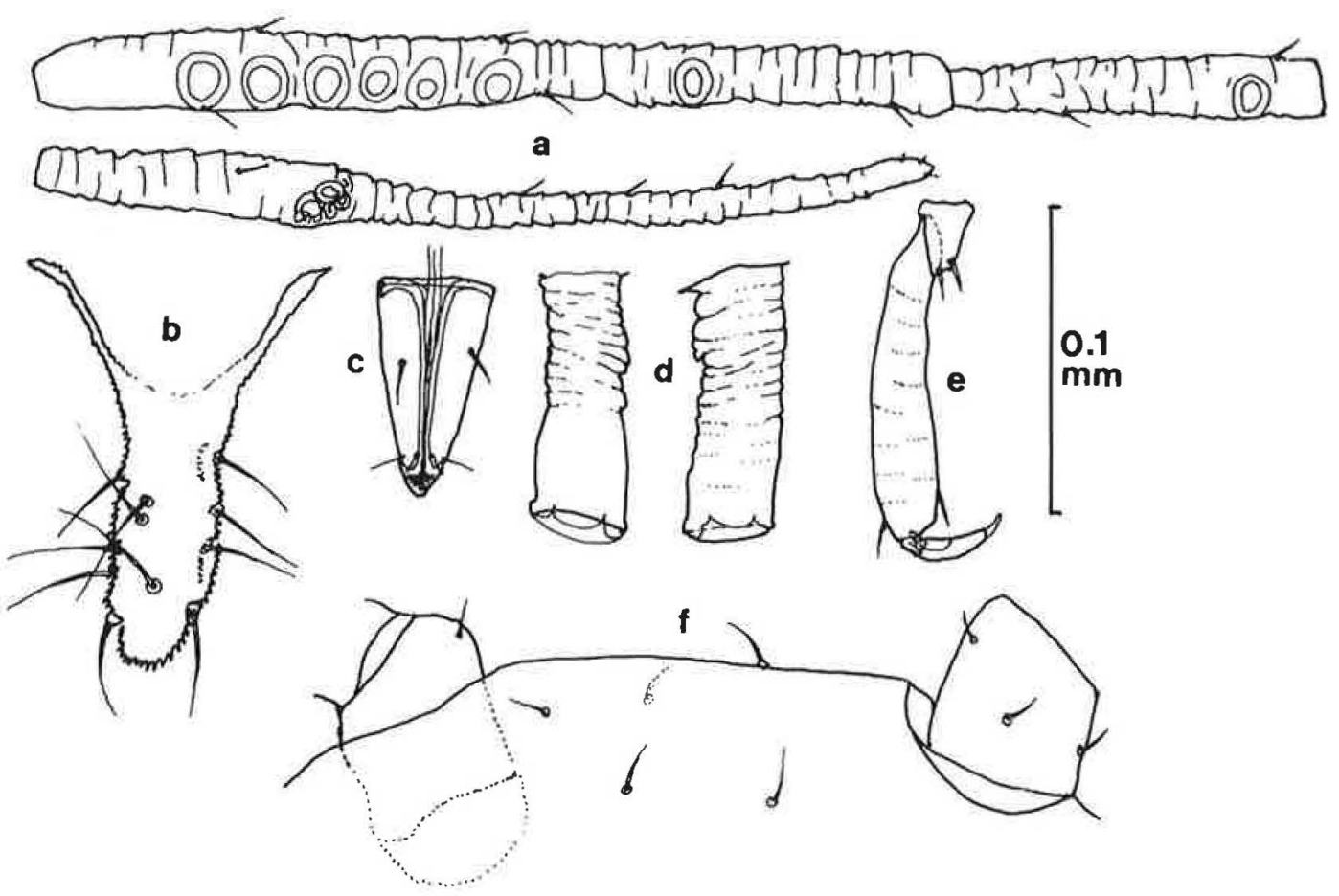

Fig. 9. Melanaphis elisabethae (Ossiannilsson). Virgo alata. a: antennal segments III-VI; b: cauda; c: apical rostral segment; d: two types of siphunculi; e: metatarsus; f: anterior part of the head. Scale $0.1 \mathrm{~mm}$.

\section{Schizaphis dubia (Fig. 10)}

Material: N: Vantaa 668:39 al from suction trap 3.VIII.1992.

Diagnostic characters: Pettersson (1971a) described and illustrated the species thoroughly. It is a member of the $S$. graminum complex. S. dubia differs from other species of the $S$. graminum complex in having a long PT (PT/B = 4-5), and a total absence of marginal tubercles on the abdomen. Antennal setae are longer than in S. borealis and $S$. agrostis. In the alate specimen (broken) captured in Finland the ratio HL ant III/bd ant III is
0.8 , in $S$. agrostis and in $S$. borealis 0.5 . The ratio $\mathrm{Si} / \mathrm{Ca}$ is 1.69. Lateral frontal tubercles are as low as the median one. The shape of the cauda is broader than in the alatae of $S$. agrostis or $S$. borealis. SR on ant III is $5-8$ of al. The apex of Si is slightly dusky.

Biology: In the host plant tests (Pettersson 1971b), S. dubia has accepted several different host plants, e.g. Bromus, Calamagrostis, mostly C. canescens, Hordeum, Milium, Poa. In natural conditions Calamagrostis canescens is the most popular host plant.
Fig. 10. Schizaphis dubia Huculak. Virgo alata. a: antennal segments III-V; b: cauda; c: apical rostral segment; d: siphunculus; e: metatarsus. Scale $0.2 \mathrm{~mm}$.
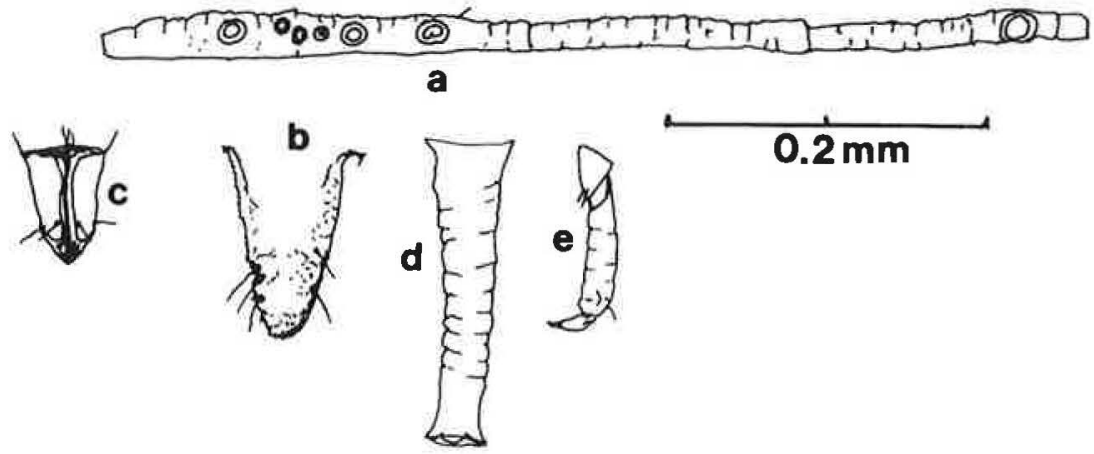


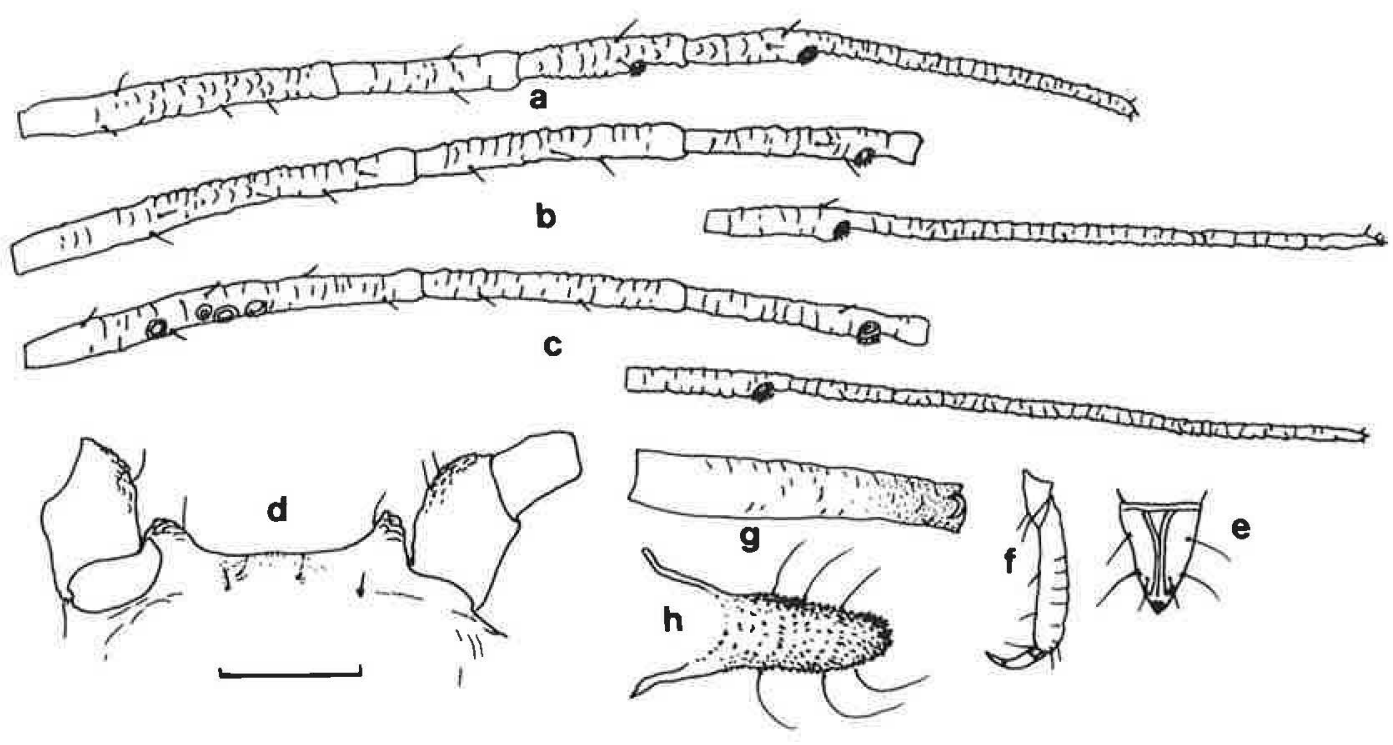

Fig. 11. Schizaphis jaroslavi (Mordvilko). Fundatrix (a), virgo aptera (b, d-h) and virgo alata (c). a-c: antennal segments III-VI; d: antennal segments I and II and anterior part of the head; e: apical rostral segment; f: metatarsus; g: siphunculus; h: cauda. Scale $0.1 \mathrm{~mm}$.

\section{Schizaphis jaroslavi (Fig. 11)}

Material: $N$ : Vantaa 668:39 al from wnt 21.VII.1963, apt on Calamagrostis sp. 23.VI.1963; $K b$ : Liperi 694:63 fx, apt and al 2.VII.1994 on Calamagrostis epigeios (A. Albrecht \& O. Heikinheimo leg.); Ks: Kuusamo 736:60 apt on Calamagrostis epigeios 29.VII.1967.

Diagnostic characters: The species is a member of the S. graminum complex (Heie 1986), the apterous aphids are light green with a darker green median stripe along the dorsum. The special characters of $S$. jaroslavi are the triangular Ars with pointed apex, the smooth $\mathrm{Si}$ without a dilation at the apex, the finger-like Ca with a sign of constriction in the middle. The ratio $\mathrm{Si} / \mathrm{Ca}$ varies between 1.0-1.4, and PT/B between 4.3-5.2. Marginal tubercles occur on abd I and VII only. Their diameter is about twice as great as in $S$. agrostis. The ratio Ars/Ht2 varies between $0.70-0.85$. The number of SR on ant III are 4-5 in al, rarely 0-3 only.

Some biometric data on virgo aptera: Body $1.7-2.3 \mathrm{~mm}$; ant f 1.05-1.40; PT 0.37-0.45; Si 0.21-0.26; Ca 0.17-0.22; Ars $0.08-0.11$; Ht2 0.11-0.13; Tib III 0.67-0.86. Number of: CH 5-7. Ratio of: ant f/body $0.57-0.68$; Si/body $0.11-$ 0.15 ; PT/B 3.64-4.36; PT/ant III 1.29-1.57; Si/Ca 1.151.38; Ars/Ht2 0.69-0.81.

Fundatrix is similar in virgo aptera, but the appendices are shorter.
Biometric data of fundatrix: Body $2.25 \mathrm{~mm}$; ant f 0.85 ; PT 0.25; Si 0.17; Ca 0.18; Ars 0.085; Ht2 0.11; Tib III 0.70. Number of CH 6. Ratio of: ant f/body 0.38; Si/body 0.076; Si/Ca 0.96; PT/body 0.11; PT/ant III 1.05; Ars/Ht2 0.76.

Biometric data of virgo alata: Body $1.3-1.9 \mathrm{~mm}$, ant $\mathrm{f}$ 1.14-1.39; P' $0.40-0.48$; Si 0.15-0.19; Ca 0.15-0.18, Ars $0.08-0.09$; Ht2 0.11-0.13; Tib III 0.7-0.9. Number of CH 5-8. Ratio of: ant f/body $0.65-0.88 ; \mathrm{Si} /$ body $0.09-0.12 ; \mathrm{PT} /$ B 3.77-4.29; PT/ant III 1.33-1.63; Si/Ca 0.97-1.20; Ars/ $\mathrm{Ht} 20.52-0.85$.

Biology: The aphids live monoeciously on $\mathrm{Ca}$ lamagrostis epigeios growing in dry sandy places; they turn the leaves bluish red and roll them upwards bearing the aphids inside.

\section{*19. Schizaphis nigerrima (Fig. 12)}

Material: $N$ : Vantaa 668:39 al from wnt 13.VII.1960; $T b$ : Saarijärvi 695:41 three apt on Calamagrostis purpurea 4.VIII.1978 (P. Alanko leg.); Om: Revonlahti 717:40 al from wnt 30.VII. 1962.

Remarks: Hille Ris Lambers (1931a, 1939a), Eastop (1961), Stroyan (1957, 1966, 1984) and Heie (1986) have all described the species and repeated a variety of characters which differ in some respects from each other. Earlier, Schizaphis laingi Eastop, 1961 and S. nigerrima have been considered independent species (Eastop \& Hille 


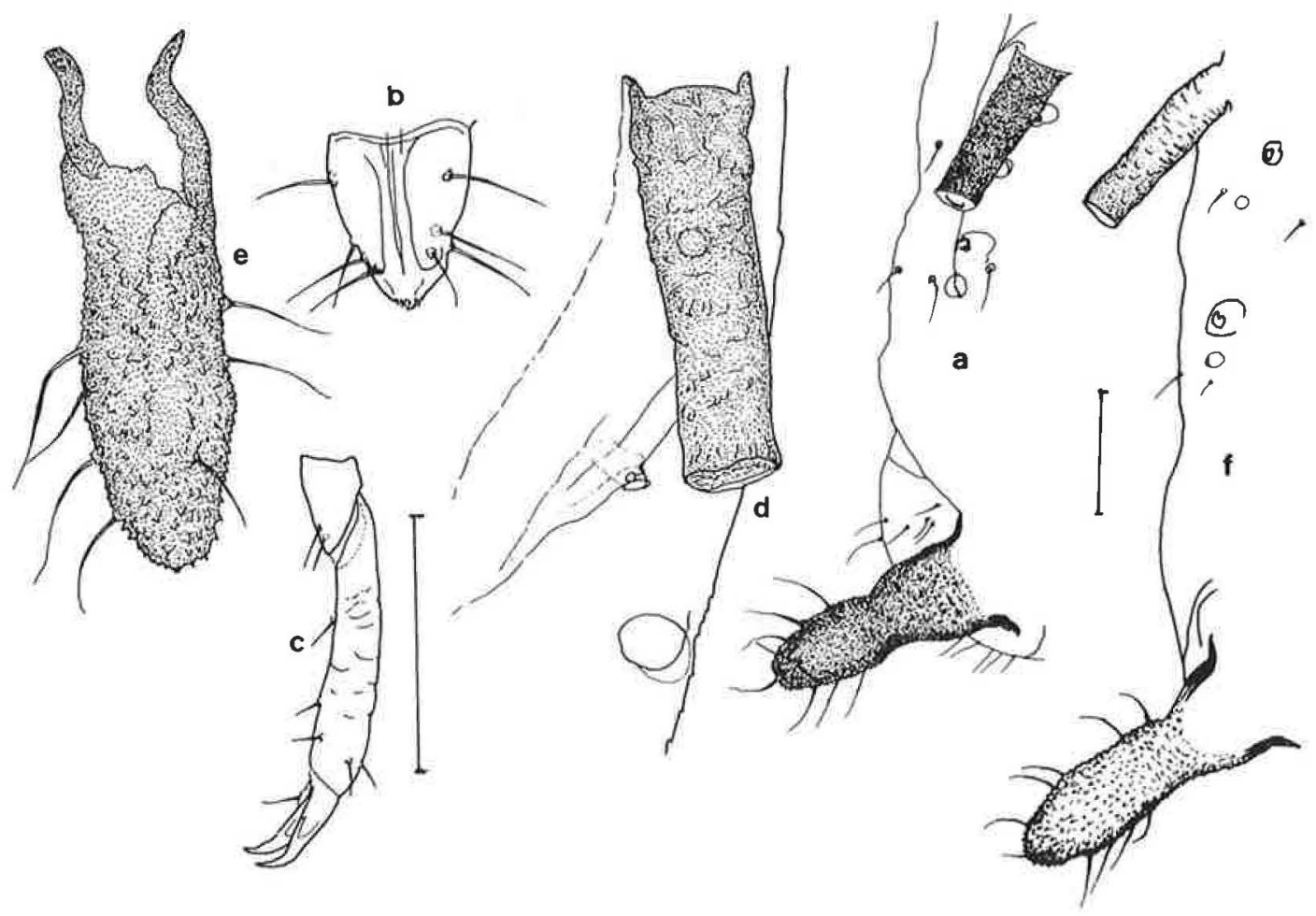

Fig. 12. Schizaphis nigerrima (Hille Ris Lambers.). Virgo alata (a), virgo aptera (b-e). Schizaphis longicaudata Hille Ris Lambers. Virgo alata ( $f$ ). a, f: siphunculus, cauda and marginal tubercles; b: apical rostral segment; c: metatarsus; d: siphunculus; e: cauda. Scales $0.1 \mathrm{~mm}$.

Ris Lambers 1976). Stroyan (1984) first placed S. laingi as a junior synonym of S. nigerrima: “... the characters used to separate laingi from nigerrima are not constant and seem to be generational differences." According to Eastop (1961), lateral abdominal tubercles are present in S. nigerrima only on segments I and VII, whereas in S. laingi lateral tubercles are present also on segm. VI and variably on II-V. In $S$. laingi the ratio $\mathrm{Si} /$ body is $0.06-0.09$, PT/B 2.0-2.8, PT/ant III 0.9-1.25, ant f/body $0.33-0.55$, and HL abd III/bd III 1.0. CH are 6-9. SR are 4-7 distributed on ant III. In $S$. nigerrima the ratio PT/B is $3.0-3.75, \mathrm{Si} / \mathrm{Body}$ 0.9-0.11 and HL Ant III/bd III about 2.0. Abd tubercles appear only on abd I and VII, and they are very small, their diameter being the same as that of the stigma or smaller.

Diagnostic characters: The most striking diagnostic characters of the specimens collected in Finland are the evenly dark siphunculi and dark cauda. All three apterous specimens have large marginal tubercles on segments I and VII of the abdomen (22-25 $\mu \mathrm{m}$ in diameter). Marginal tubercles are present also on segment VI (15-20 $\mu \mathrm{m}$ in diameter), and one specimen also had four additional tubercles on segments II-IV $(10 \mu \mathrm{m}$ in diameter). Setae on tergite VIII are short, about $20-34 \mu \mathrm{m}$ in length. Pleural intersegmental sclerites, siphunculi and cauda are black. Hence the characters agree well with the description of S. laingi by Eastop (1956) except the length ratio of PT/B which is similar to $S$. nigerrima.

The specimens much resemble Schizaphis longicaudata Hille Ris Lambers, 1939. However, the latter has longer and pale cauda (length ratio $\mathrm{Si} / \mathrm{Ca}=0.64-0.72$ ), and the siphunculi are pale with a dusky apical part. The marginal tubercles are distinctly smaller (diameter on abd VI 8-12 and on abd VII 12-18 $\mu \mathrm{m}$ ).

Biometric data on the apterous viviparous females from Saarijärvi (measurements in mm): Body $2.00 \mathrm{~mm}$; ant f 1.21 , 1.5; ant III 0.30, 0,32, B 0.10, 0.11, PT 0.32, 0.40; Si 0.16$0.17 ; \mathrm{Ca} 0.16,0.20 ;$ Ars 0.073, 0.078; Ht2 0.12-0.13. Length ratios: Ant f/body 0.61-0.77; Si/body 0.08-0.11; PT/B 3.2- 


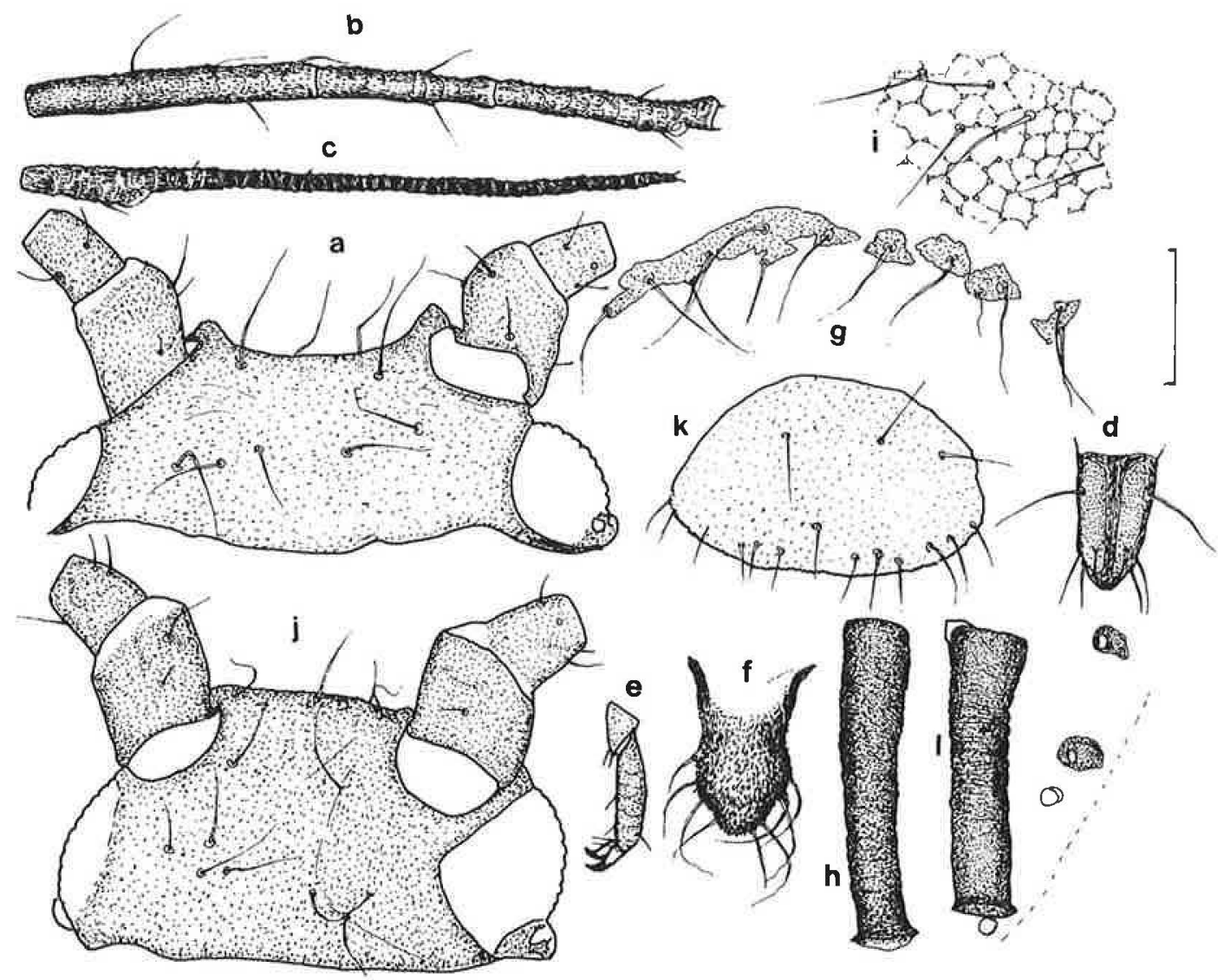

Fig 13. Schizaphis (Paraschizaphis) caricis (Schouteden). Ovipara (a-i) and virgo alata ( $\mathrm{j}-\mathrm{I})$. a, j: head and antennal segments I and II; b, c: antennal segments III-VI; d: apical rostral segment, e: metatarsus; f: cauda; g: pigmentation and setae of abdominal segment VIII; $h$, I: siphunculus; i: structure and setae on abdominal segment IV; $\mathrm{k}$ : arrangement of setae on genital plate. Scale $0.1 \mathrm{~mm}$.

3.6; PT/ant III 1.26-1.34; PT/Ht2 0.86; Si/Ca 0.85, 1.00; Ars/Ht2 0.61; HL ant III/bd III 0.5. Number of CH 6. Diameter of marginal tubercles: on abd VI 13 (18) 25, on abd VII 18 (25) $29 \mu \mathrm{m}$.

Biometric data on the alate viviparous female from Revonlahti (measurements in mm): Body $1.92 \mathrm{~mm}$; ant $\mathrm{f} 1.40$; ant III 0.360, B 0.12, PT 0.43; Si 0.14; Ca 0.20; Ars 0.076; Ht2 0.12. Length ratios: Ant/body 0.73; Si/body 0.07; PT/ B 3.54; PT/ant III 1.18 Si/Ca 0.81; PT/Ht2 3.54; Ars/Ht2 0.63 ; HL ant III/bd III 0.5-0.6. Diameter of marg. tub, on abd VI 15, 18, on abd VII $25,30 \mu \mathrm{m}$.

\section{Schizaphis (Paraschizaphis) caricis (Fig. 13)}

Material: Ab \& St: Nousiainen \& Yläne, Kuhankuono 674:25 23.VII.1994 on Carex rostrata, C. limosa, C. lasiocarpa and C. spp. (A. Albrecht, O. Heie \& O. Heikinheimo leg.); $N$ : Hanko 664:28 24.VIII.1993 on Carex rostrata (A. Al- brecht leg.); Helsinki rural mun. 668:39 al on Poaceae 30.IV.1950; Sipoo, Savijärvi 669:4022.VIII.1993 on Carex diandra (A. Albrecht leg.); St: Rauma 679:20 al swept 2.VII.1986; Ta: Janakkala 676:38 fx and apt on Carex sp. 4.V.1991 (Veli Vikberg leg.); Sa: Mikkeli 684:51 al from wind net trap 30.VII.1967; Om: Revonlahti 717:40 al from wind net trap 7.VII.1962; Pyhäntä 710:46 al on Carex rostrata 28.VI.1989; Ks: Kuusamo 735:60 ovip on Carex buxbaumi 7.IX.1986.

The black colored aphid of this species is a typical member of the genus Schizaphis in having once-forced media in forewings of alatae and the characteristic situation of the marginal tubercles on abd I and VII. Antennae, siphunculi and cauda are black. The members of the subgenus are long-haired all over. This species differs from the closely related $S$. scirpi in having only four occipital setae on the head. The aphids live on 
Carex and Scirpus, also on subterranean parts, and are visited by ants.

Some biometric data on two virgo aptera: Body length 2.00-2.05 mm; HL abd III 0.07 and abd VIII $0.085 \mathrm{~mm}$. Length ratios: Ant/body 0.66, 0.68; Si/body 0.16, 0.17; Si/ Ca $1.9,2.00 ;$ PT/B 5.0, 5.4; PT/Ant III 1.9, 2.3; Ars/Ht2 1.15, 1.23; HL ant III/bd III 2.2, 2.7. Number of $\mathrm{CH}=10$.

Fundatrix differs from virgo aptera in having shorter antennae, legs and siphunculi.

Some biometric data on the fundatrix: Body $1.85 \mathrm{~mm}$; PT 0.32. Length ratios: ant/body 0.53; PT/B 2.8; PT/ant III 1.33; Si/Ca 1.5; Ars/Ht2 1.2.

Virgo alata: In the specimens from Finland the hair lengths are as described in the virgo aptera. Siphunculi are shorter (Si/body 0.4), PT/B 4.27, and number of $\mathrm{CH} 7$.

Oviparae $(n=3)$ have about 30 scent plaques on each hind tibia.

Some length ratios: PT/B 4.3; Si/body 0.11-0.13; HL Ant III/bd III 2.6-3.0.

\section{Aphis avicularis}

Material: $N$ : Vantaa 668:39 al and male from wind net trap 26.VII.1967.

Diagnostic characters: The very short, pale siphunculi of these dark-colored alatae with numerous rhinariae on antennal segments III-V are the most conspicuous characters of this species (Stroyan 1984).

Some biometric data on the virgo alata: Body length $1.2-1.6 \mathrm{~mm}$; Ant f 0.74-1.01; Si 0.085-0.112; Ca 0.1300.156; Ars 0.08-0.104; Ht2 0.095-0.13; Tib 0.61-0.87. Number of: SR III 4-17, IV 0-7, V 0-1; MT on II-VI 0-1; CH 5-6; SH 2. Ratio of: Ant/body 0.62-0.74; Si/body 0.680.84; PT/B 1.82-2.15; PT/ant III 0.69-1.20; Si/Ca 0.640.79 ; Ars/Ht2 0.80-0.85; HL ant III/bd III 0.5.

\section{Aphis fabae ssp. mordvilkoi}

Material: $N$ : Helsinki 667:38 apt on Arctium tomentosum 9.VII.1945 (Esko Suomalainen leg), 6.VIII.1947 and 14.VII.1992 on Arctium tomentosum (A. Albrecht leg.), Helsinki 667:39 25.VII.1993 on Arctium tomentosum (A. Albrecht leg.); Sipoo, Nevas 668:41 13.VII.1991 on Arctium tomentosum (A. Albrecht leg.); Ta: Hämeenlinna 676:36 28.VII.1994 on Arctium tomentosum (A. Albrecht, O. Heie \& O. Heikinheimo leg.); Sa: Joutseno 678:57 on Arctium tomentosum 7.VII.1957 as A. fabae s. lat. (Thuneberg 1960);
Sb: Joroinen 685:54 apt, al on Arctium tomentosum 22.VIII.1911 and on A. minus 31.VII.1910 (T. J. Hintikka leg.).

Diagnostic characters: Viburnum serves as a primary host, Arctium and Tropaeolum (?) as a secondary. No other ssp. of $A$. fabae have been observed to live on these host plants (Stroyan 1984). It is not possible to show morphological differences between A. f. mordvilkoi and other ssp. from individuals or small samples. According to Stroyan, the variation of the length of setae on antennae A. f. mordvilkoi lies between A. fabae s.str. and A. f. cirsiiacanthoidis, greatly overlapping each other in variation ranges.

\section{Aphis genistae}

Material: N: Espoo 667:37 LL on Genista tinctoria (in greenhouse, import from The Netherlands) 8.IV.1980.

\section{Aphis longirostrata}

Material: $N$ : Tvärminne 664:28 8.VII.1993 (A. Albrecht leg.); Helsinki, Santahamina 667:39 25.VII.1993 (A. Albrecht leg.); St: Rauma 679:19 virgines apterae 16.VII.1987. All records from Plantago maritima.

The long rostrum, the long apical rostral segment, the numerous large marginal tubercles, and the very short antennal hairs are the most striking diagnostic characters of this species.

Some biometric data on the apterous viviparous females from Finland: Body length 1.2-1.54 mm. Number of: MT on abd II-VI 10, their diameter/bd ant III 1.5-2.0; CH 6-8. Ratio of: Ant f/body 0.50-0.59; Si/body 0.12-0.15; PT/B 2.42-2.75; Si/Ca 1.33-1.93; Ars/Ht2 1.42-1.61; HL ant III/ bd III $<0.5$.

\section{Aphis podagrariae}

Material from Finland: $N$ : Vantaa 668:39 apt on Aegopodium podagraria 28.VII.1980; Ta: Pälkäne 680:35 apt and al on Aegopodium podagraria.

Diagnostic characters: One of the "black aphids", closely related to A. fabae. The species is characterised by the long and thin setae, almost totally absent of the marginal tubercles on abdominal segments II-VI ( 1 and 2 tubercles on segm. II, two cases of 10 ), and by the rather long apical rostral segment. In these characters it differs from ssp. of A. fabae. 

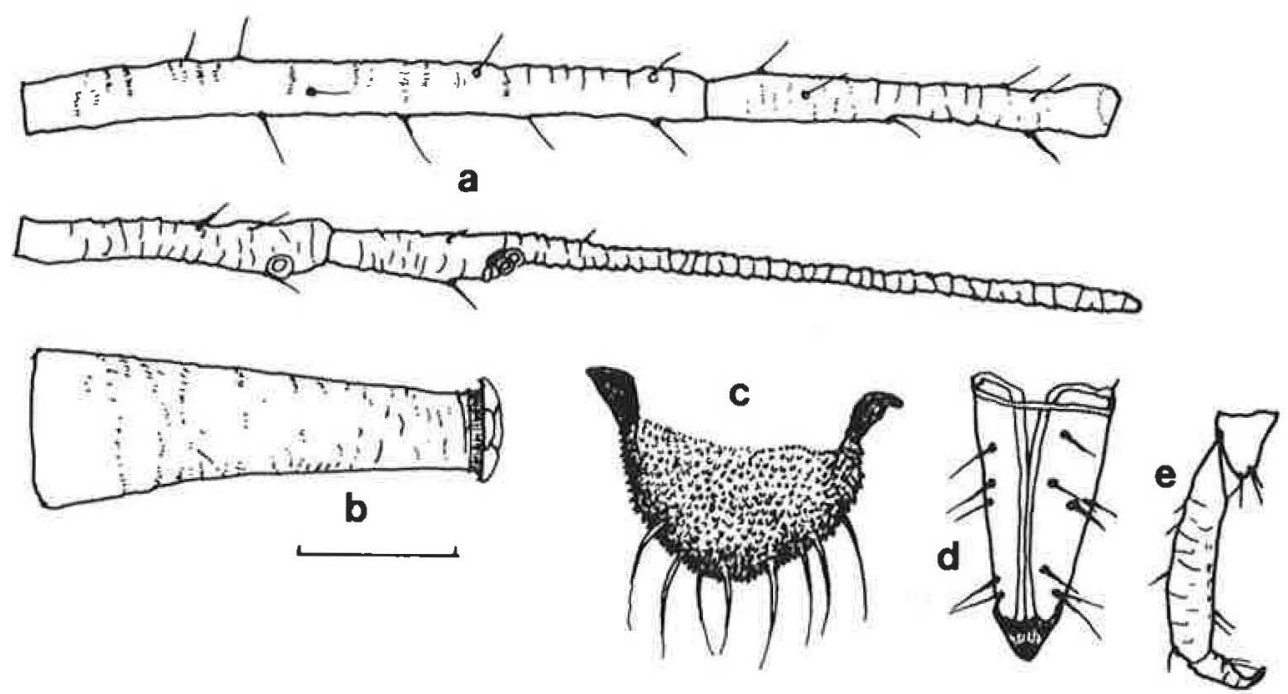

Fig. 14. Brachycaudus (Acaudus) aconiti (Mordvilko). Virgo aptera. a: antennal segments III-VI; b: siphunculus; c: cauda; d: apical rostral segment; e: metatarsus. Scale $0.1 \mathrm{~mm}$.

Some biometric data on the apterae and alatae from Finland: Body length $1.28-1.45$; Si apt $0.12-0.15$, al 0.10 0.12 ; Ars 0.11-0.12. Number of SR of al ant III 9-11, IV 45, V 0; CH 12-17. Ratio of: ant f/body: apt 0.59-0.63, al 0.72-0.73; Si/body apt 0.10, al 0.08-0.09; PT/B 2.39-2.69; $\mathrm{Si} / \mathrm{Ca}$ apt 1.12-1.24, al 0.96-1.13; Ars/Ht2 1.12-1.27; HL ant III/bd III 1.62-2.22.

Biology: Monophagous on Aegopodium podagraria in tightly curved leaves.

\section{Aphis umbrella}

Material: $N$ : Helsinki 667:38 apt and al on Althaea rosea 1.VII.1951 (Martti Markkula leg.).

Diagnostic characters: The alate specimens resemble A. nasturtii (Kalt.) but differ in having antennal segments III and IV about equal in length, having longer siphunculi and more numerous and larger marginal tubercles on the abdomen. Their diameter varies, often exceeding the diameter of the tip of the siphunculi.

Some biometric data on virgo alata: Body length 1.66$2.00 \mathrm{~mm}$; Ars 0.12-0.14; Tib. III 1.00-1.07. Number of: SR ant III 6-11, IV 0-2, V 0; MT on abd II-VI 6-10; CH 8-11. Ratio of: ant f/body 0.57-0.71; ant III/IV 0.78-1.13; PT/B 1.55-2.46; Si/Ca 1.83-1.95; Ars/Ht2 1.11-1.35; HL ant III/bd III $0.7-0.8$.

\section{*27. Brachycaudus (Acaudus) aconiti (Fig. 14)}

Material: N: Helsinki 667:383.VI.1992 and 2.VI.1993 colonies on Aconitum septentrionale, A. variegatum, and $A$. napellus (A. Albrecht leg.); apt. sexuparae, ovip. and males on Aconitum napellus 6.VIII.1992; Ta: Hämeenlinna 676:36 apt on 24.VII.1990 and 19.VII.-7.VIII.1991 on Aconitum cammarum. Thuneberg (1962) mentioned B. napelli found 12.VII.1960 in the same place on A. napellus as the first mentioned (Helsinki).

It is obvious that the determination of Thuneberg's sample, the slide made by Ossiannilsson about $1960-61$, is really $B$. aconiti, because by that time only $B$. napelli was known from Europe outside the Soviet Union. Later on Shaposhnikov (1964) considered B. aconiti as a subspecies of B. napelli, but Stroyan (1964) and Eastop and Hille Ris Lambers. (1976) as an independent species. Hence $B$. napelli must be deleted from the list of the Finnish aphid fauna.

Shaposhnikov (1964), Stroyan (1964), Burger (1975) and Lampel (1988) have described and keyed the diagnostic characters of $B$. aconiti and $B$. napelli. The main discriminant characters of virgines apterae of these species are as follows (Burger 1975):

- B. napelli: Ratio Si/Ht2 1.0-1.3. Metatarsus I with 2 hairs. Ant III usually with several rhinaria. 
- B. aconiti: Ratio Si/Ht2 1.6-2.4. Metatarsus I with 3 hairs. Ant III usually without rhinaria.

Some biometric data on virgo aptera: Body length 2.35$2.70 \mathrm{~mm}$; SR on ant III 0 (1). Ratio of: Si/Body 0.10-0.13; PT/B 2.64-3.34; PT/Ant III 0.83-0.88; Si/Ht2 2.00-2.29; Ars/Ht2 1.19-1.32; HL ant III/bd III 1.10-1.23.

Sexupara aptera: Body length $2.3-2.5 \mathrm{~mm}$; SR on ant III 0-3 (mean 1.0). Ratio of: SI/Body 0.11-0.13; PT/B 2.823.02; PT/Ant III 0.96-0.99; Si/Ht2 1.91-2.11; Ars/Ht2 1.251.32; $\mathrm{HL}$ ant III/bd III 1.00-1.10.

Description of ovipara: Body of larvae and ground color of adults brown, pigmented parts black. Abdominal dorsum with isolated spinal, pleural, muscular and marginal sclerites, moderate in their size, or fused into spino-pleural segmental bands. Hind tibiae hardly swollen, with only 0-6 scent plaques.

Biometric data: Body length: $2.0-2.2 \mathrm{~mm}$; Ant III 0.24 0.28 ; B $0.110-0.114$; PT 0.28-0.51; Si 0.20-0.23; Ars 0.16$0.165 ; \mathrm{Ht} 2$ 0.125-0.135; Tib III 0.77-0.90. Number of: $\mathrm{SH}$ 9-12. Ratio of: Ant/body 0.44-0.60; Si/body 0.10-0.12; PT/ B 2.56-2.79; PT/ant III 1.11-1.24; Si/Ht2 1.59-1.99; Ars/ $\mathrm{H}+2$ 1.22-1.30; HL ant III/bd III 1.00-1.19.

Description of apterous male: Body color of larvae and ground color of adults green. Antennal segments III and IV have a tendency to be fused. Secondary rhinaria small, often in small groups distributed up to the very tip of antennal segments III and IV. Abdominal dorsum with segmental spino-pleural bands, large marginal scleroites, and between them having smaller muscle and other sclerites irregular in shape. Segments VII and VIII with narrow bands.

Biometric data: Body length 1.5-1.7 mm. Ant III 0.270.32 ; B 0.07-0.10; PT 0.30-0.34; Si 0.17-0.21; Ars 0.150.16; HT2 0.12-0.125; Tib III 0.76-0.82. Number of SR on ant III 16-25, IV 12-19, V 4-9. Ratio of: ant f/body $0.63-$ 0.70; Si/body 0.10-0.13; PT/B 3.06-4.40; PT/ant III 0.981.14; Si/Ht2 1.41-1.68; Ars/Ht2 1.22-1.28; HL Ant III/bd III 1.04-1.42.

Biology: Alatae viviparae appeared during the first generations in May-June only, the first apterous males already during the first weeks of August.

\section{Brachycaudus (Acaudus) linariae Stroyan, 1957}

Misidentification: Dysaphis aizenbergi (Heikinheimo 1990).
Remarks: The structure of the abdominal stigmae, the non-protruding secondary rhinaria on the antennae, and the roundish cauda of the virgo alata, all indicate that the aphid, described erroneously as Dysaphis aizenbergi (Heikinheimo 1990), belongs to the genus Brachycaudus (Shaposhnikov 1964). It has virtually the same characters as the species $B$. linariae Stroyan. As a consequence, the report of Heie (1992) concerning the observation of Dysaphis aizenbergi (Shaposhnikov, 1949) from Finland is wrong, and this name must be deleted from the list of aphid fauna of Finland. Therefore his description of the alata, according to the material from Finland, refers to $B$. linariae Stroyan.

Material: $N$ : Vantaa 668:39 al 26.VII.1963 and 18.VI.1966 from wnt, al 16.VII.1981 from suction trap.

The most striking diagnostic character of the alatae is the sclerotization of the abdominal dorsum, in which the pigmented patch is segmentally broken, and covers only tergites IV-VI without reaching the marginal sclerites. Other characters of $B$. linariae are the shortness of the setae on the antennae and on the abdominal tergum, the length of the siphunculi, and the length ratios between body, siphunculi, parts of antennal segment VI, the apical rostral segment, and the 2nd metatarsal segment.

Biometric data: Body length I.6-1.9 mm; ant III 0.320.36 ; Si 0.24-0.28; Tib III 0.86-0.98. Number of SR ant III 31-42,VI 4-10, V 1-2; MT 5-8 (flat and weakly bordered), CH 8-11, SH 8-9. Ratio of: Ant f/body 0.70-0.71, Si/body 0.15 ; PT/B 3.85-4.30; PT/ant III 1.22-1.30; Si/Ca 2.642.82; Ars/Ht2 1.02-1.20; HL ant III/bd III 0.35-0.45; HL abd III/bd III 0.35-0.45; HL abd VIII/bd III 0.48-0.55.

\section{Semiaphis anthrisci}

Material: Ta: Joutseno apt 27.VIII.1963 as Semiaphis sp. (Thuneberg 1966), apt, ovip and nymph 26.IX.1965, both on Peucedanum palustre (E. Thuneberg leg.).

Diagnostic characters: According to Heinze (1960) and Heie (1992) Semiaphis anthrisci differs from S. pimpinellae and S. dauci in the shape of the cauda, siphunculi, and apical rostral segment and in the length ratios of the measurements. However, the differences are small, and overlapping of characters occurs in many cases between 


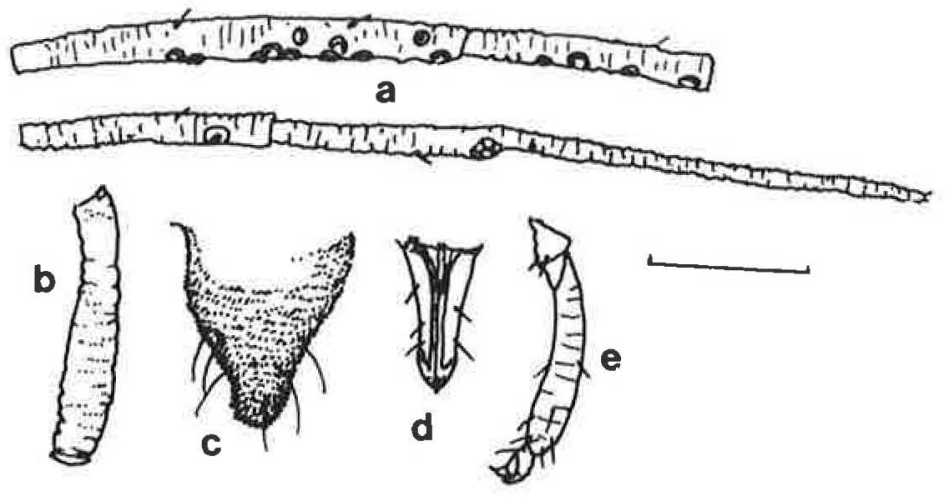

Fig. 15. Coloradoa inodorella Ossiannilsson. Virgo alata. a: antennal segments III-VI; b: siphunculus; c: cauda; d: apical rostral segment; e: metatarsus. Scale: $0.1 \mathrm{~mm}$. species. In addition to different host plants, the most distinct discriminant characters between species are the differences in the length of setae on antennal segment III, and on the dorsum of abdominal segments III and VIII as follows:

$$
\text { dauci anthrisci pimpinellae }
$$

Length of setae on:

$\begin{array}{lccc}\text { Ant III } \mu \mathrm{m} & 7-8 & 10-13 & 15-20 \\ \text { Abd III } \mu \mathrm{m} & 7 & 15-20 & 26-30 \\ \text { Abd VIII } \mu \mathrm{m} & 10-12 & 22-35 & 35-48\end{array}$

Biometric data on virgo aptera: Body length $1.95 \mathrm{~mm}$; ant III 0.23; B 0.75; PT 0.17; Si 0.09; Ca 0.17; Ars 0.09; Ht2 0.105 . Ratio of: ant f/hody 0.50 ; Si/body $0.007 ;$ PT/B 2.27; Si/Ca 0.52; Ars/Ht2 0.86; HL ant III/bd III 0.52; HL abd III/bd III 1.54; HL abd VIII/bd III 2.69; Si/basal width 1.69; $\mathrm{Ca} /$ basal width 1.57: Ars/basal width 2.43.

Alate viviparous female: the nymph was collected just before emerging so that the number of secondary rhinaria could be calculated: SR ant III 29, 36; IV 7, 9; V 1, 3.

Oviparous female: Much like the apterous viviparous female but a little smaller. Hind tibiae strongly swollen, with very numerous scent plaques. The lengths of setae as in virgo aptera.

\section{Coloradoa inodorella (Fig. 15)}

Material: $N$ : Vantaa 668:39 al from suction trap 20.VII.4.VIII.1982; Ta: Lahti 676:42 18.IX.1991 on Tripleurospermum inodorum (A. Albrecht leg.) .

Diagnostic characters: The swollen siphunculi, the fairly short and broad-triangular and pointed cauda, and the number of secondary rhinaria in the alatae are typical for this species in addition to the host plant species of this monophagous species.
Biometric data on six virgines alatae: Body length 1.00$1.70 \mathrm{~mm}$; Ant. f 0.71-1.18; Si 0.12-0.18; Ca 0.08-0.12; Ars $0.072-0.092 ; \mathrm{Ht} 20.084-0.125$. Number of: SR ant III 8-17, IV 5-10, V 1-6. Ratio of: Ant/body 0.59-0.79; Si/body 0.09-0.15; Tib III/body $0.41-0.50 ;$ PT/B $1.55-2.24 \mathrm{Si} / \mathrm{Ca}$ 1.33-1.91; Ars/Ht2 0.71-0.94; HL ant III/bd III 0.40-0.63.

\section{Ossiannilssonia oelandica (Fig. 16)}

Material: N: Vantaa 668:39 al from wind net trap 25.VI.1966.

Diagnostic characters: The virgo aptera has been described by Hille Ris Lambers (1952b), Ossiannilsson (1959) and Heie (1992).

Description of virgo alata: Body pale, basal 1/5 part of antennal segment pale, the rest pigmented. Legs, siphunculi and cauda dusky. Median and lateral frontal tubercles very low. Apical rostral segment as long as broad, with roundish apex. Marginal tubercles on abdominal segments II-V small, each situated on the top of low conical elevation. Unpaired spinal tubercles on segments VII and VIII narrow, finger-shaped, parallel-sided, $0.07 \mathrm{~mm}$ long. On segment VI the unpaired tubercle as long as broad, roundish. On abd segment $\mathrm{V}$ only one of the paired tubercles in this specimen is visible, this is situated on one side of the median line. Segments I-IV without such spinal tubercles. Siphunculi as in virgines apterae. Cauda strongly constricted on basal $2 / 5$, the apical part fingershaped, almost parallel-sided, with five setae.

Biometric data on virgo alata: Body length $1.48 \mathrm{~mm}$; Ant III 0.395; B 0.14; PT 0.30; ant $\mathrm{f} 1.30$; Si 0.07; Ca 0.19; Ars 0.08; Ht2 0.11; Tib III 0.92. Number of: SR III 9-11, IV 0, V 0; CH 3; SH 2. Ratio of: Ant f/body 0.88; Si/body 0.048; PT/B 2.19; PT/ant III 0.76; Si/Ca 0.37; Ars/Ht2 0.74; HL ant III/bd III $<0.4$. 


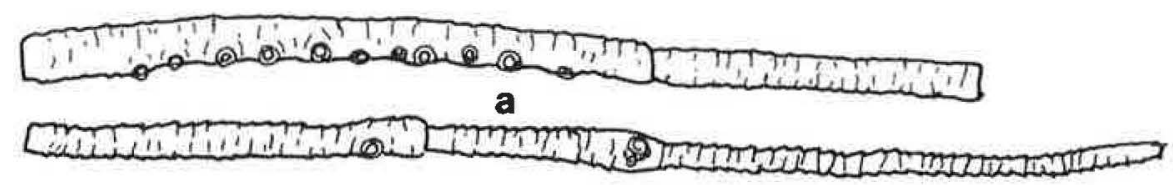

Fig. 16. Ossiannilssonia oelandica Hille Ris Lambers. Virgo alata. a: antennal segments III-VI; b: abdomen; c: apical rostral segment; d: siphunculus; e: metatarsus. Scales 0.2 and $0.5 \mathrm{~mm}$.

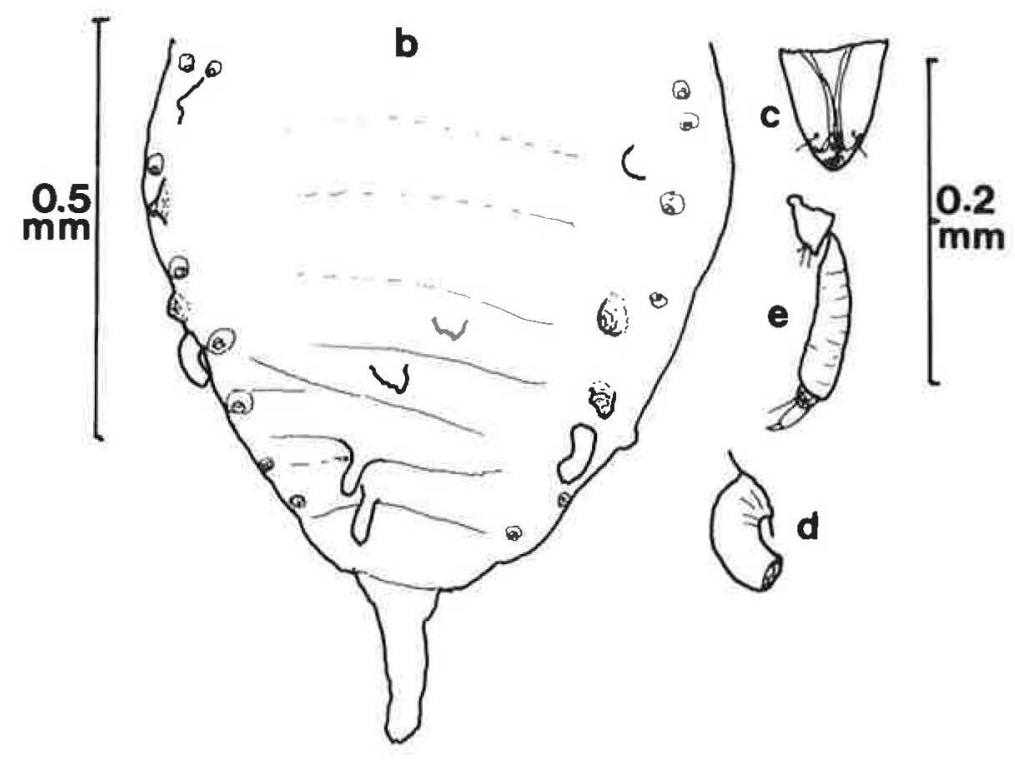

\section{Myzus (Nectarosiphon) certus (Fig. 17)}

Material: Al: Jomala 669:11 1 al 1.X.1962; $N$ : Vantaa 668:39 1 al 26.VII.1963. Both from wnt.

Diagnostic characters: The species very much resembles Myzus (Nectarosiphon) persicae (Schulzer, 1776), but in $M$. (N.) certus SH are 4-7 instead of 2, and SR may be also on ant segm. IV. According to Hille Ris Lambers (1966), PT is shorter than $\mathrm{Si}$ in summer apterae. On the underside of the abdomen are prominent pigmented markings. Siphunculi are slightly shorter and more swollen than in $M$. (N.) persicae. In life the aphids are red or brown in color; in $M$. (N.) persicae the ground color is green (Taylor 1980, Heie 1994).

Biometric data on two alatae: Body length 1.62, 1.88 mm; ant f 1.42, 1.63; ant III 0.41, 0.45; B 0.14, 0.16; PT $0.40,0.45$; Si 0.31, 0.34; Ca 0.16, 0.17; Ars 0.10, 0.11; Ht2 0.105 . Number of SR ant III 9-11, IV 0-1, V 0; SH 5, 7; CH 6. Ratio of: Ant/body $0.87,0.88$; Si/body $0.18,0.19$; PT/B 2.81, 2.96; PT/ant III 0.98, 1.01; Si/ant III 0.75, 0.76; $\mathrm{Si} / \mathrm{Ca} 1.94,1.97$.

Biology: The species lives monoecious on Cerastium, Stellaria and Viola tricolor.

\section{Submegoura heikinheimoi (Fig. 18)}

Material: $N$ : Vantaa 668:39 two al from wind net trap 11.VII.1966.

The main diagnostic characters of alatae are the swollen siphuculi, the only once-branched media of forewings, the lack of the dark central sclerite of the abdomen, and the tuberculate rhinaria arranged in a row on antennal segment III (Hille Ris Lambers 1953, Heinze 1961).

Some biometric data from two virgines alatae: Body length $2.13,2.27 \mathrm{~mm}$; ant III 0.77, 0.78; B 0.175; PT 0.82; Si 0.44, 0.45; Ca 0.17, 0.19; Ars 0.11; HT2 0.12; Tib III 1.60, 1.62. Number of SR Ant III 15-18, IV 13, V 0; CH 8; SH 2. Ratio of: Ant/body 1.21; Si/body 0.19, 0.21; Tib III/ body $0.71,0.75$; PT/B 4.67; PT/ant III 1.05; Si/Ca 2.28, 2.65; Ars/Ht2 0.91; HL ant III/bd III $<0.5$.

\section{Sitobion paludum}

Remarks: Müller (1982) first found and reared this species which overwinters on Vaccinium uliginosum and moves to Rhynchospora alba in sum- 


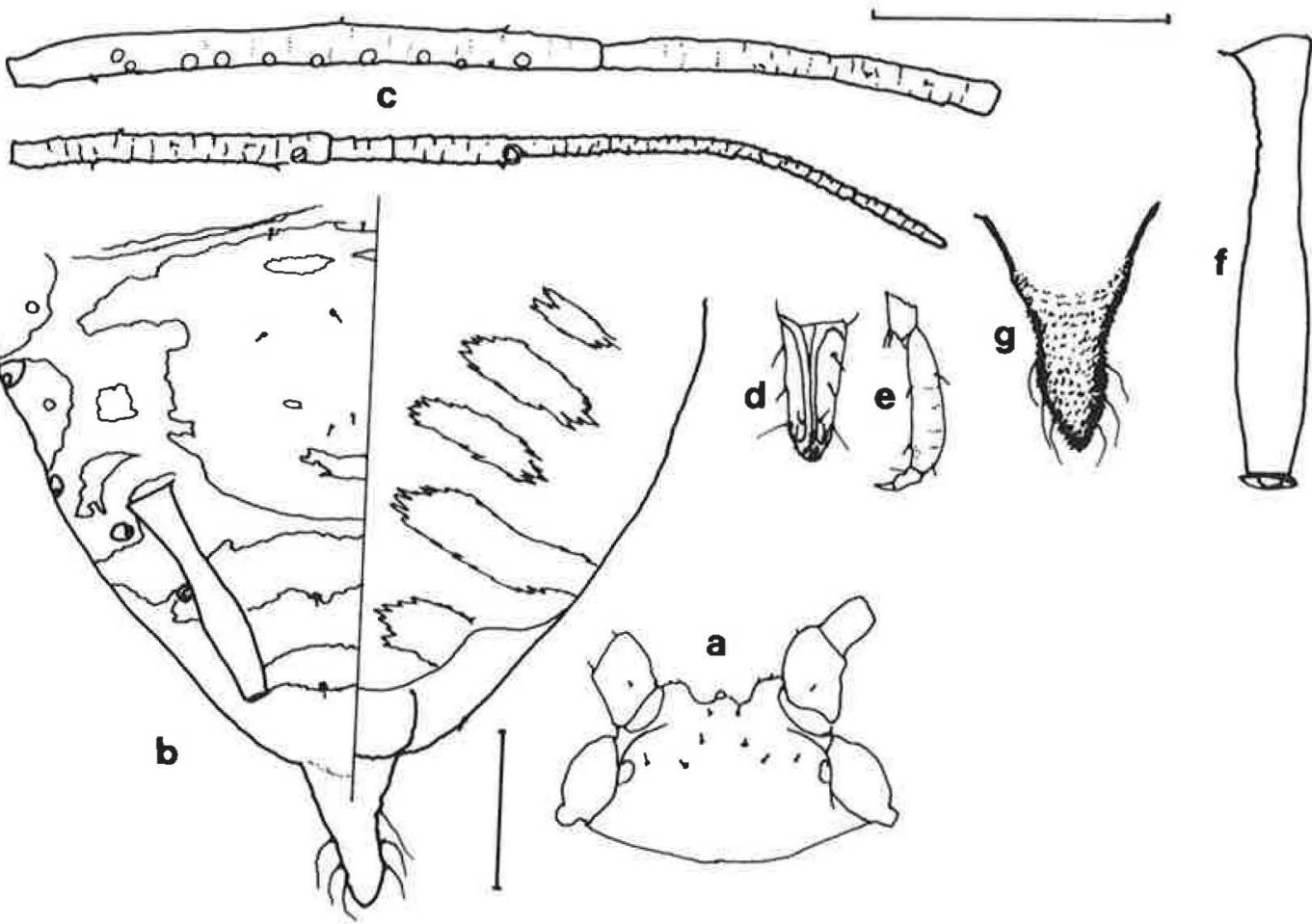

Fig. 17. Myzus (Nectarosiphon) certus (Walker). Virgo alata. a: head; b: pigmentation of abdomen; c: antennal segments III-VI; d: apical rostral segment; e: metatarsus; f: siphunculus; g: cauda. Scales $0.2 \mathrm{~mm}$.

mer. Owing to its high similarity to the common Sitobion avenae (F.) the species has been overlooked earlier. According to the descriptions of Müller (1982), Heie (1994) suggested how the two species can be distinguished from each other according to their length ratios Si/body and Si/Ca. The Sitobion aphid specimens from Finland which looked most like the descriptions of Müller are
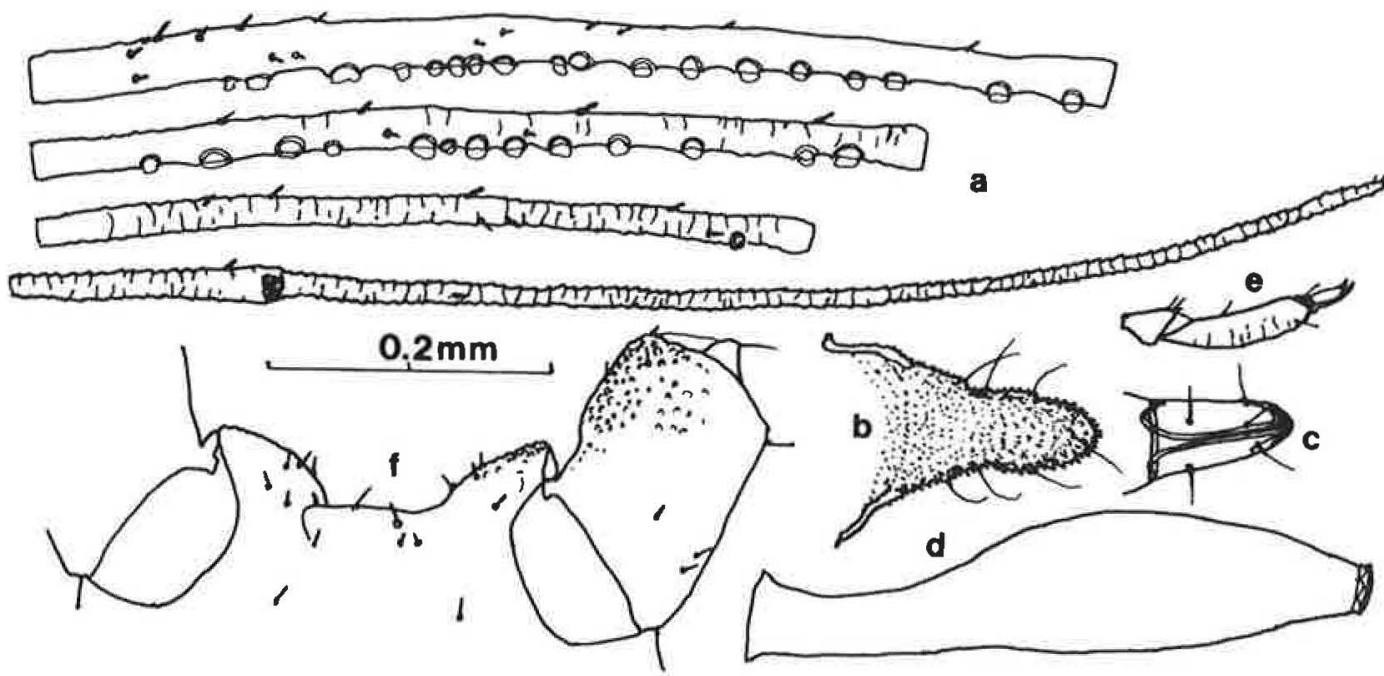

Fig. 18. Submegoura heikinheimoi (Börner). Virgo alata. a: antennal segments III-VI; b: cauda; c: apical rostral segment; d: siphunculus; e: metatarsus; f: anterior part of the head and antennal segment I. Scale $0.2 \mathrm{~mm}$. 
measured and compared with the limit ratios of Heie (1994) (Fig. 19).

Material: The following samples have been considered to represent the species in question: $T b$ : Konnevesi 694:46 apt, al 27.VI.1989; Sb: Kiuruvesi 708:47 apt, al 28.VI.1989 (Martti Koponen and O. Heikinheimo leg); Juankoski 701:56 al. 18.VI.1988; Om: Pyhäjoki 715:35 apt 6.VIII.1979; Pyhäntä 710:47 apt, al 28.VI.1989; Kn: Paltamo 714:55 10.VII.1989; Puolanka 720:54 apt, al. 29.VI.1989; LKemW: Kittilä 753:43 apt. 8.VII.1989; Li: Inari 766:50 apt 13.VIII.1964. All aphids have been captured with a sweep net from bogs or meadows of different types.

Diagnostic characters: The host plant is the best character to identify the species. If not known, the suitable habitat and the measurements of $\mathrm{Si}$, $\mathrm{Ca}$, and body may supply the information needed.

\section{Delphiniobium junackianum}

Material: $N$ : Helsinki 667:38 on Aconitum variegatum 3.VI.1992 and 2.VI.1993 (A. Albrecht leg.); apt. on Aconitum sp. 31.VII.1985; apt, al, ovip on Aconitum ranunculifolium and A. variegatum 21.IX.1990 apt on A. napellus; Ta: Hämeenlinna 676:36 apt, al, ovip and males on $A$. cammarum and A. variegatum 24.VII.-15.XI.1990; fx on A. cammarum 7.VI.1991.

Diagnostic characters: Lampel (1988) described and pictured the species thoroughly. The host plant and the green-blue color of these large, slightly shining aphids is the most conspicuous character. Antennae, siphunculi, cauda and legs are black.

Biology: The aphid live on upper parts of the shoots and on the leaves of Aconitum. The first alate males appeared in the last week of August, the first oviparae one month later. On 15 November all kinds of morphs were still alive below minus $7^{\circ} \mathrm{C}$ at night.

\section{Macrosiphoniella dimidiata (Fig. 20)}

Syn: Macrosiphoniella fasciata Thuneberg, 1966 (nec Del Guercio, 1913 = absinthii (Linnaeus, 1758)).

Material: Ab: Naantali 671:22 apt, al 23.VII.1994 (Osmo Heikinheimo, Ole Heie \& Anders Albrecht leg.), 8.IX.19.X.1994 apt, oviparae, apt. males; $N$ : Vantaa 668:39 al from wnt 18-29.VII.1963; Ka: Hamina 671:51 apt 29.VII.1982; Ta: Janakkala 675:37 apt 25.VII.1994 (Osmo Heikinheimo, Ole Heie \& Anders Albrecht leg.); Sa: Joutseno 678:57 apt, al 26.VII.1963, 13.VI.1964 apt (E. Thune-

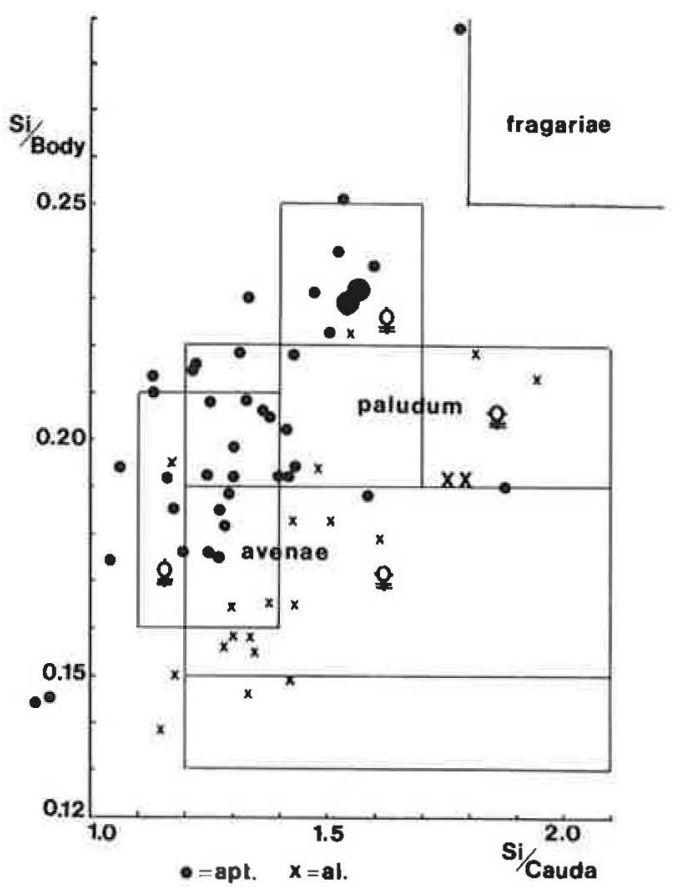

Fig. 19. Sitobion avenae (Fabricius), S. paludum F. P. Müller and $S$. fragariae (Walker). Length ratios of siphunculi/body and siphunculi/cauda of virgo alata and virgo aptera aphid specimens most closely resembling $S$. paludum. Limits of these two characters for the three species are represented as quadrangles according to Heie (1994). Four paratypes of Müller for S. paludum have larger signs. Only some of the specimens represented have been interpreted as S. paludum.

berg leg.). All records except those from the traps are collected from Artemisia campestris.

Additional description of the virgo aptera: Head, antennae except basal 1/4 of segment III, tibiae, tarsi, distal part of femora, siphunculi and cauda black, on abdominal segments I-VII dark marginal and antesiphuncular sclerites and spinal bands and smaller pleural scleroites, and on segment VIII a broad band bearing four setae. The spinal bands may be splinted into isolated scleroites with one seta on each. Secondary rhinaria on antennal segment III almost in a row, fairly flat, not in groups. Marginal tubercles on abdomen very small, their diameter about $2 / 5$ of the diameter of the stigmal aperture. Siphunculi almost cylindrical, slightly dilated towards the apex, flangeless. Cauda constricted gradually in their middle, and narrowing gradually towards the apex. 


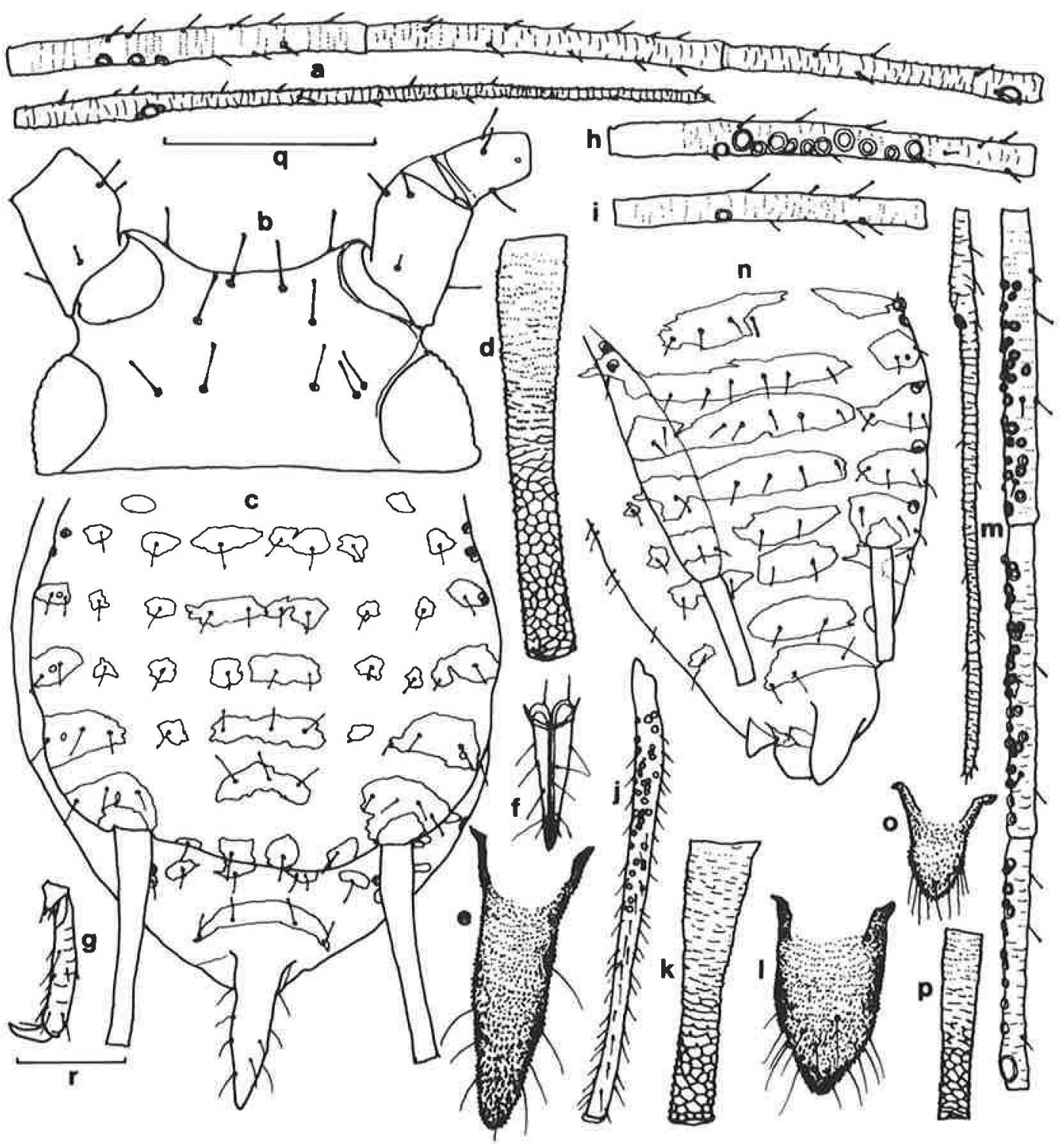

Fig. 20. Macrosiphoniella dimidiata Börner. a-g: Virgo aptera; h: virgo alata; i-l: ovipara; $m-p$ : male. a, m antennal segments III-VI; h, i antennal segment III; b head and antennal segments I and II; c, $\mathrm{n}$ dark patterns on abdomen; d, k, p siphunculus; e, I, o cauda; $f$ apical rostral segment; $g$ metatarsus; j metatibia. Scales 0.2 $\mathrm{mm}, \mathrm{r}$ for $\mathrm{c}, \mathrm{n}, \mathrm{j} ; \mathrm{q}$ for the others.

Biometric data: Body length 1.7-2.0 mm; ant III 0.320.41 , ant IV 0.33-0.37, B 0.12-0.14; PT 0.53-0.544; Si $0.43-0.47$; Ca 0.27-0.31; Ars 0.13-0.14; Ht2 0.127-0.135; Tib III 1.18-1.21. Number of: SR on ant III 1-6; MT on abd II-VI 1-6; CaH 9-12; SH 6; mesh zones on Si about 16-21. Length ratios: Ant f/body 0.87-0.96; Si/body 0.230.26; PT/B 3.79-4.24; PT/ant III 1.33-1.66; PT/Si 1.161.26; Si/Ca 1.42-1.60; Ars/Ht2 0.97-1.10; HL ant III/bd III 0.77-0.79; HL abd III/bd III 0.97-1.10.
Virgo alata: Pigmented areas as in virgo aptera, but sclerites on abdomen small, splinted more or less into isolated scleroites. Small spinal bands on abdominal segments II and VIII, on abd VIII a broad spinopleural band with four setae. Secondary rhinaria distributed on the outer side of the segment, not in a row, moderate in size, in part quite near each other. Siphunculi similar to those 
in virgo aptera. Cauda narrow, pointed, constricted near their base.

Biometric data: Body length 1.87-2.05 mm; ant III $0.41-0.49$; ant IV $0.35-0.42$; B 0.13-0.14; PT 0.53-0.55; Si $0.38-0.47$; Ca 0.26-0.33; Ars 0.137-0.140; HT2 0.132 0.142; Tib III 1.23-1.32. Number of: SR on ant III 12-14, ant IV and V 0; MT on abd II-VI 1-8; CaH 8-12; SH 6; mesh zones on SI about 16-22. Length ratios: Ant f/body 0.92-0.94; Si/body 0.19-0.23; PT/B 3.97; PT/Ant III 1.32; PT/Si 1.27; Si/Ca 1.36-1.65; Ars/Ht2 0.99-1.05; HL ant III/bd III 0.81-1.17; HL abd III/bd III 1.32-1.50.

Ovipara: Pigmentation as in virgo aptera. Abdomen with isolated spinal scleroites, spinopleural bands on abd segments VII and VIII only. Abd segm. VIII with 10 setae. Secondary rhinarium on ant segm. III fairly small. Siphunculi much smaller than in virgo aptera, with fewer mesh zones. Cauda short and broad, without constriction, with a blunt apex. Metatibia swollen in their basal part, with about 40 scent plaques.

Biometric data: Body length 1.66-1.94 mm; ant III $0.24-0.30$; Si $0.28-0.32$; Ca 0.15-0.19; Ars 0.21-0.26; Ht2 $0.106-0.113$; Tib III 0.82-0.96. Number of: SR ant III 1-2, VI and V 0; MT 0(1); CaH 10-12; mesh zones on Si about 9-11. Length ratios: Ant f/body 0.64-0.82; Si/body 0.110.17; PT/B 3.33-3.80; PT/Ant III 1.32-1.66; PT/Si 1.242.05; $\mathrm{Si} / \mathrm{Ca} 1.33-2.05 ; \mathrm{Ars} / \mathrm{Ht} 2$ 1.07-1.18.

Male: Apterous. Pigmentation almost as in virgn aptera, but tibiae in their middle half paler, and abdominal dorsum with broad spinopleural bands reaching on segments III and IV to the marginal sclerites. The broad spinopleural band on abdominal segment VIII with four setae. Secondary rhinaria fairly small, mostly on the outer side, distributed over the entire length on segments III and IV, on segm. V on the middle 3/4 part. Siphunculi small, almost as in ovipara. Cauda as in ovipara, but narrower.

Biometric data: Body length 1.12-1.57 mm; ant III 0.28-0.35; ant IV 0.27-0.35; B 0.11-0.14; PT 0.42-0.49; Si 0.19-0.22; Ca 0.11-0.14; Ars 0.11-0.12; Ht2 0.11-0.12; Tib III 0.82-0.93. Number of: SR ant III 23-32, ant IV 2030, ant V 9-13; MT 0-1; CaH 7-8; SH 5-7, mesh zones 813 on Si. Length ratios: Ant f/body 0.96-1.19; Si/body 0.130.17; PT/B 3.45-3.98; PT/ant III 1.26-1.46; PT/Si 2.052.32; Si/Ca 1.48-1.73; Ars/Ht2 0.94-1.05; Tib III/body $0.59-0.73$; HL abd III/bd III 1.28-1.52.

\section{Comments}

Börner (1942) described how the virgines apterae of the species differ from the closely related
M. teriolana Hille Ris Lambers, 1931 and M. subaequalis Börner, 1942, all of which live on Artemisia campestris. According to Börner the discriminant characters are:

- the relative length of the mesh zone on the siphunculi, which is about $0.42-0.44$ in $M$. dimidiata, 0.40 in $M$. teriolana, of the length of the siphunculi

- the number of mesh zones on the siphunculi being 18-23 in $M$. dimidiata and 14-16 in $M$. teriolana

- the number of secondary rhinaria on antennal segment III, 7-14, always two, sometimes three together in tightly placed groups in $M$. dimidiata, 4-6 in M. teriolana

- the length ratio processus terminalis/siphunculus being 1.11 in M. dimidiata, 1.25 in M. teriolana.

Macrosiphoniella subaequalis has shorter siphunculi; the mesh zone on the siphunculi reaches only 0.33 of the length of thesiphunculi and includes 10-12 mesh zones only. The setae on the antennae and abdominal dorsum are longer than in M. teriolana and M. dimidiata (Börner 1942).

Some measured characters of $M$. teriolana (Hille Ris Lambers 1931a, 1938) fall into the same ranges as with $M$. dimidiata, measured from the Finnish material. Such include the number of secondary rhinaria, and the length of antennal setae. On the other hand, the setae on the abdomen are longer (2.0-2.5 $\times$ bd ant III) in M. teriolana (1.301.67 in $M$. dimidiata), the siphunculi are shorter, about $0.27 \mathrm{~mm}, 0.17-0.2 \times$ body in $M$. teriolana $(0.38-0.47 \mathrm{~mm}, 0.23-0.26 \times$ body in $M$. dimidiata), the cauda is shorter, about $0.19 \mathrm{~mm}, 0.67-$ $0.80 \times$ the length of siphunculi in $M$. teriolana (0.27-0.31 mm, 0.62-0.70 $\times$ the length of siphunculi in $M$. dimidiata), and the number of caudal hairs 4-8 only in $M$. teriolana (9-12 in M. dimidiata).

The virgines apterae collected in Finland differ from the description of $M$. dimidiata (Börner 1942 ) in having only $1-6$ secondary rhinaria on their third antennal segment ( 6 and 6 in one case only of 30 ), the mean number being 3 (Börner: $7-$ 14). According to Heie (in litt.), the number of sec. rhinaria in Denmark and Germany varies between $2-10$ in the virgines apterae. The length ratio siphunculus/mesh zone varies between 0.30 0.45 (Börner: 0.42-0.44), and the number of mesh zones between 16-21 (Börner: 18-23).The length 
ratio processus terminalis/siphunculus varies between 1.16-1.26 (Börner: 1.11). In spite of the differences mentioned above, the populations from Finland are nearer to $M$. dimidiata than to M. teriolana, from which they differ for instance in the length of setae on the abdomen and in the length of siphunculi.

Biology: The species lives on the upper parts of the host Artemisia campestris. The oviparae and apterous males appeared during September.

\section{Uroleucon jaceicola}

Material: N: Vantaa 668:39 al from wind net trap 25.VIII.1962.

The very long siphunculi, short pale cauda, and numerous tuberculate secondary rhinaria on the whole length of the third antennal segment (Hille Ris Lambers 1939b) are conspicuous diagnostic characters in which the species clearly differs from Uroleucon (Uromelan) jaceae (Linné, 1758). Both live on the same host plant, Centaurea jacea.

Some biometric data from one virgo alata: Body length $3.50 \mathrm{~mm}$; Number of: SR on ant III 78, 77; $\mathrm{CH} 7$; SH 4 . Length ratios: Ant f/body 1.07; Si/body 0.33; Tib III/ body 0.65; PT/B 5.89; PT/ant III 0.91; Si/Ca 3.15; Ars/Ht2 1.33; HL ant III/bd III 1.1.

\section{Megourella purpurea}

Material: $N$ : Vantaa 668:39 al from wind net trap 11.VIII.1962, al from suction trap 10.VII.-3.VIII.1982; Om: Revonlahti 717:40 al from wind net trap 21,-24.VII.1962.

Diagnostic characters: These dirty reddish or greenish violet aphids have large dark roundish sleroites on the dorsum in four rows. Antennae are long, black, with only a few rhinaria on segm. III. The cauda is elongated, pale. The very base of all tibiae is pale; in the closely related $M$. tribulis (Walker, 1849) the tibiae are entirely black. Siphunculi are black, slightly swollen (Hille Ris Lambers 1949). Small marginal tubercles on abdominal segments II-VI vary in their shape from pointed conical to protruding blisters.

Some biometric data from eight virgines alatae: Body length 2.12-2.68; Number of SR on ant III 24-38, IV 6-15, V 0; MT on abd II-VI 3-8; CH 6-8. Length ratios: Ant f/ body $1.17-1.34$; Si/body $0.15-0.18$; Tib III/body $0.66-0.77$;
PT/B 3.25-4.46; PT/ant III 0.75/1.03; Si/Ca 1.33-1.58; Ars/ Ht2 $0.88-1.00$.

Biology: The aphids live on the lower parts of Lathyrus pratensis.

\section{Galiaphis annae (Fig. 21)}

Material: $O b N$ : two al. from Rovaniemi rural mun. 738:45, 22. and 26.VII.1966 in wnt.

Diagnostic characters: The most striking diagnostic characters of the alatae are the membranous and light tergum, the very long antennae with only a few rhinaria on segm. III, and the swollen siphunculi with a long cylindrical basal part (Ossiannilsson 1954).

Biometric data: Body length 1.78 and $1.88 \mathrm{~mm}$; ant $\mathrm{f}$ 2.36 and 2.63; ant III 0.49-0.56, IV 0.47-0.53, V 0.38 0.41 , B $0.15-0.19$, PT 0.85-0.94; Si 0.39-0.43; Ca 0.17 and 0.18 ; Ars 0.09 and 0.10 ; HT2 0.105 and 0.107. BD of ant III $0.028-0.029$. CH 4, SH 3, on 1st tarsal segm: 3-3-2 setae. SR ant III 7-8. Length ratios: PT/B 4.70-5.48; Ars/ Ht2 0.86-0.89; Si/Ca 2.35 and 2.38; Si/body 0.22 and 0.23 . HL ant III/bd III 0.3, HL abd IV/bdIII 0.4.

Remarks. The alate specimens from Finland differ from the description of Ossiannilsson (1954) in having shorter cauda, distinctly less than $0.5 \times$ the length of siphunculi. The specimens from Finland are smaller than those from Sweden, but in other respects they are very similar.

Biology: The aphids live on stems and leaves of Galium boreale (Ossiannilsson 1954).

\section{Lachnidae}

\section{Eulachnus brevipilosus}

Material: Kl: Rautjärvi 681:62, al on Pinus sylvestris 29.VI.1990.

Diagnostic characters: The species is characterised by the very short pointed setae on the antennae and abdominal tergum (Carter \& Maslen 1982). According to their description, the shape of the setae on frons and on legs are sturdy and capitate. The siphunculi are small and the perisiphonal sclerites inconspicuous.

Some biometric data on the virgo alata: Body length $1.86 \mathrm{~mm}$; Tib III 1.20. Lengths of setae in mm: Frons of the head 40-50, ant III 18, abd III 11, abd VIII 36-68, Tib III up to 60 . 

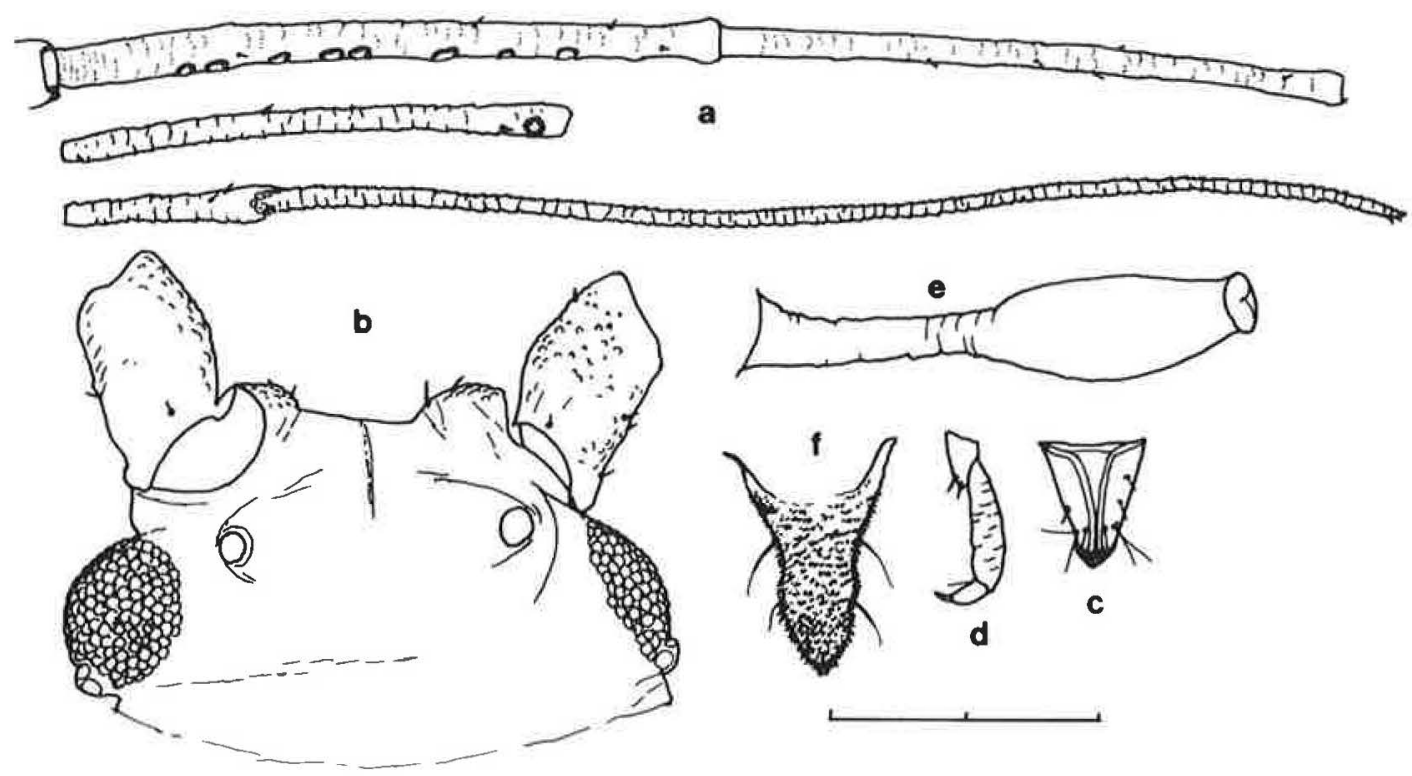

d

c

Fig. 21. Galiaphis annae Ossiannilsson. Virgo alata. a: antennal segments III-VI; b: head with antennal segments I; c: apical rostral segment; d: metatarsus; e: siphunculus; f: cauda. Scale $0.2 \mathrm{~mm}$.

Acknowledgements. I am grateful for Prof. Ole E. Heie's valuable advice and information about the taxonomic problems of some species, and for Dr. Anders Albrecht's useful discussions during the preparation of the manuscript. I thank Dr. Carol Norris for checking my English.

\section{References}

Albrecht, A. 1992a: Baizongia pistaciae (Linnaeus) (Homoptera, Pemphigidae) new to Finland. - Entomol. Fennica 3: 5 .

- 1992b: Geoica setulosa (Passerini) (Homoptera, Pemphigidae) new to Finland. - Entomol. Fennica 3: 5.

- 1992c: Protrama flavescens (Koch) (Homoptera, Lachnidae) new to Finland. - Entomol. Fennica 3: 5-6.

- 1992d: Smynthurodes betae Westwood (Homoptera, Pemphigidae) new to Finland, — Entomol. Fennica 3: 6

- 1993a: Anoecia zirnitsi Mordvilko (Homoptera, Anoeciidae) new to Finland. - Entomol. Fennica 4: 10.

- 1993b: Aphis lotiradicis Stroyan (Homoptera, Aphididae, Aphidinae) new to Fennoscandia. - Entomol. Fennica 4: 11.

- 1993c: Aphis species new to Finland (Homoptera, Aphididae, Aphidinae). - Entomol. Fennica 4: 11.

- 1993d: Macrosiphine aphids new to Finland (Homoptera, Aphididae, Macrosiphinae). - Entomol. Fennica 4: 11-12.

- 1993e: Mamontova vera Shaposhnikov (Homoptera, Aphididae, Macrosiphinae) new to Nordic countries.Entomol. Fennica 4: 12.
- 1993f: Phyllaphidine aphids new to Finland (Homoptera, Drepanosiphidae, Phyllaphidinae). - Entomol. Fennica 4: 12.

- 1993g: A record of Semiaphis nolitangere (Aizenberg) (Homoptera, Aphididae, Macrosiphinae) from Finland. — Entomol. Fennica 4: 12-13.

- 1994a: Aphis klimeschi, A. leontodontis and A. violae (Homoptera, Aphididae) new to Finland. - Entomol. Fennica 5: 3-4.

- 1994b: Aphis epilobiaria and A. molluginis (Homoptera, Aphididae) new to Finland. - Entomol. Fennica 5: 4.

- 1994c: Chaitophorus populialbae (Boyer de Fonscolombe) (Homoptera, Drepanosiphidae) new to Finland. - Entomol. Fennica 5: 4-5.

- 1994d: Uroleucon pilosellae (Börner) (Homoptera, Aphididae) new to Finland. - Entomol. Fennica 5: 5.

Blackman, R. L. 1989: Cytological and morphological differences within palearctic Glyphina (Homoptera: Aphididae), and their taxonomic significance. - Systematic Entomol. 14: 7-13.

Börner, C. 1942: Weitere neue europäische Blattlausarten. — Veröffentl. Dtsch. Kolonial- u. Übersee-Mus. 3: 259 276.

Burger, H. C. 1975: Key to European species of Brachycaudus, subgenus Acaudus (Homoptera, Aphidoidea), with redescriptions and a note on $\mathrm{B}$. persicae. Tijdschr. Entomol. 118: 99-116.

Carter, C. I. \& Danielsson, R. 1991: Two spruce root aphids, Pachypappa vesicalis and Pachypappella lactea new to Britain with illustrated keys to the morphs from Picea roots. - The Entomologist 110: 66-74. 
Carter, C. I. \& Maslen, N. R. 1982: Conifer Lachnids. Forestry Commiss. Bull. 58: 1-75.

Eastop, V. F. 1956: Keys to the British species of Schizaphis Börner, s.str. (Homoptera: Aphididae) and the description of a new species. - Entomol. Mon. Mag. 92: 268-270.

- 1961: A key for the determination of Schizaphis, Börner (Aphididae, Hem.). — The Entomologist 94: 241-246.

Eastop, V. F. \& Hille Ris Lambers, D. 1976: Survey of the World's aphids. - Dr. W. Junk b.v., Publishers, The Hague, 573 pp.

Heie, O. 1980: The Aphidoidea (Hemiptera) of Fennoscandia and Denmark I. - Fauna Entomol. Scand. 9: 1-236.

- 1982: Ibid. II. - Fauna Entomol. Scand. 11: 1-176.

- 1986: Ibid. III. - Fauna Entomol. Scand. 17: 1-314.

- 1992: Ibid. IV. — Fauna Entomol. Scand. 25: 1-189.

- 1994: Ibid. V. - Fauna Entomol. Scand. 28: 1-241.

Heikinheimo, O. 1984: The aphid fauna of Finland: additions, comments and descriptions of new morphs. Notulae Entomol. 64: 33-49.

- 1990: Aphid species and morphs new to the fauna of Finland (Homoptera, Aphididae, Macrosiphini). Entomol. Fennica 1: 65-98.

- 1991: Nasonovia (Ranakimia) altaensis as an example of adaptation to short summer periods (Homoptera: Aphidinea: Aphididae). —Entomol. Gener. 16: 207-214.

- 1992: Aphidoidea of Åland, SW Finland. — Entomol. Fennica 3: 57-79.

Heikinheimo, O. \& Raatikainen, M. 1981: Grid reference and names of localities in the recording of biological finds in Finland. - Notulae Entomol. 61: 133-154

Heinze, K. 1960: Systematik der Mitteleuropäischen Myzinae mit besonderer Bericksichtigung der im Deutschen Entomologischen Institut befindlichen Sammlung Karl Börner (Homoptera: Aphidoidea-Aphididae), - Beitr. Entomol. 10: 744-842.

- 1961: Ibid III. — Beitr. Entomol. 11: 1-96.

Hille Ris Lambers, D. 1931 a: Notes on the Aphididae of Venezia Tridentina, with descriptions of new species. - Mem. Mus. Storia Naturelle Venezia Tridentina 1: 3-11.

- 1931b: Contribution to the knowledge of the Aphididae (Hom.) I. - Tijdschr. Entomol. 47: 169-183.

- 1938: Contributions to a monograph of the Aphididae of Europe I. - Temminckia 3: 1-44.

- 1939a: On some western European aphids. - Zool. Mededeel. 22: 79-119.

- 1939b: Contributions to a monograph of the Aphididae of Europe II. - Ternminckia 4: 1-134.

- 1949: Ibid IV. - Temminckia 8: 182-323.

- 1952a: The aphid fauna of Greenland. - Meddel. Groenland 136: 1-33.

- 1952b: Ossiannilssonia oelandica nov. gen., nov. sp. — Entomol. Tidskr. 73: 41-42.

- 1953: Contributions to a monograph of the Aphididae of Europe V. - Temminckia 9: 1-176.

- 1959: Notes on European aphids with descriptions of new genera and species (Homoptera, Aphididae). Mitt. Schweiz. Entomol. Ges. 32: 271-286.
- 1966: Notes on California aphids, with descriptions of new genera and new species (Homoptera: Aphididae). - Hilgardia 37: 569-623.

Huldén, L. 1985: Kommentarer till den nya katalogen (EFH/ HHY 26.9.1984). - Notulae Entomol. 65: 160.

Huldén, L. \& Heikinheimo, O. 1984: Enumeratio insectorum Fenniae. - Notulae Entomol. 64: 97-124.

Lampel, G. 1988: Nasonovia (Kakimia) werderi n. sp. und weitere für die Schweiz neue Blattlaus-Arten (Homoptera, Aphidina) 4. - Mitt. Schweiz. Entomol. Ges. 61: 253-294.

Muiller, F. P. 1982: Sitobion paludum n. sp., mit Wirtswechsel von Vaccinium uliginosum zu Gramineen (Homoptera, Aphididae). -- Entomol. Abh. Dresden 46: 99-108.

Ossiannilsson, F. 1953: Three new Swedish aphids (Hem., Hom.) with description of a new genus and a new subgenus. - Opusc. Entomol. 18: 233-238.

- 1954: Four new Swedish aphids (Hem., Hom.). With description of a new genus. - Entomol. Tidskr. 75:117 127.

- 1959:Contributions to the knowledge of Swedish aphids. I. Description of some apparently undescribed forms. - Kungl. Lantbrukshögskolans Ann. 25:1-46.

- 1967: Longiunguis elisabethae n. sp. A new Swedish aphid (Hem.). - Entomol. Tidskr. 88:130-132.

Pettersson, J. 1971a: Studies on four grass-inhabiting species of Schizaphis (Hom., Aph.). II. Morphological descriptions of populations of Schizaphis dubia Huc., S. arrhenatheri n. sp., S. rufula (Walk.) and S. longicaudata H. R. L. - Swedish J. Agric. Res. 1: 115-132.

- 1971b: Ibid. III. (a) Host plants. — Swedish J. Agric. Res. 1: 133-138.

Pintera, A. 1987: Taxonomic revision of the species of genus Chaitophorus Koch in Palearctis (Homoptera: Aphidoidea). - Deutsche Entomol. Z. 34: 219-340.

Shaposhnikov, G. Kh. 1964: 4. Suborder Aphidinea - Plant lice. - In: Bei-Bienko, G. Y. (ed.), Key to the insects of the European USSR 1: 616-799. Moscow-Leningrad.

Stroyan, H. L. G. 1953: A new British species of Calaphis Walsh (Hem., Aphididae). - The Entomol. Mon. Mag. 89: 13-16.

- 1957: Further additions to the British aphid fauna. Trans. Roy. entomol. Soc. London 109: 19-359.

- 1964: A note on two Aconitum aphids from Yugoslavia. - The Entomologist 97: 129-130.

- 1966: Notes on aphid species new to the British aphid fauna. - Proc. Roy. Entomol. Soc. London (B) 35: 111-118.

- 1984: Aphids - Pterocommatinae and Aphidinae (Aphidini) Homoptera, Aphididae. - Handbooks for the identification of British Insects 2, 6: 1-232.

Szelegiewicz, H. 1976: Aphid species (Homoptera, Aphjdodea) new to the Polish fauna. - Ann. Zool. Warszawa 33: $217-227$.

- 1982: Aphidological notes. V-X. (Homoptera, Aphidoidea). - Ann. Zool. Warszawa 36: 191-219. 
Tambs-Lyche, H. 1959: A new species of Schizaphis Börner (Hom., Aphid.) attacking Phleum pratense in Norway. - Norsk Entomol. Tidskr. 11: 88-93.

Taylor, L. R 1980: A handbook for aphid identification. Rothamsted, $171 \mathrm{pp}$.
Thuneberg, E. 1960: Beiträge zur Kenntnis der finnischen Blatt- und Schildläuse (Hom., Aphidoidea et Coccoidea) sowie deren Parasiten I. - Ann. Entomol. Fenn. 25: 97-99.

- 1962: Ibid. II. - Ann. Entomol. Fenn. 28: 40- 43.

- 1966: Ibid. IV. - Ann. Entomol. Fenn. 32: 153-158. 